This document is the accepted manuscript version of the following article:

Rougé, V., von Gunten, U., Lafont de Sentenac, M., Massi, M., Wright, P. J., Croué, J. P., \& A11ard, S. (2020). Comparison of the impact of ozone, chlorine dioxide, ferrate and permanganate preoxidation on organic disinfection byproduct formation during post-chlorination. Environmental Science: water Research and Technology, 6(9), 2382-2395. https://doi.org/10.1039/D0EW00411A

\title{
ARTICLE
}

Received 00th January 20xx, Accepted 00th January 20xx DOI: $10.1039 / x 0 x \times 00000 x$

\section{Comparison of the impact of ozone, chlorine dioxide, ferrate and permanganate pre-oxidation on organic disinfection byproduct formation during post-chlorination}

\author{
Valentin Rougé, ${ }^{a},{ }^{\dagger}$ Urs von Gunten, ${ }^{b, c, d}$ Mariette Lafont de Sentenac, ${ }^{a}$ Massimiliano Massi, ${ }^{a}$ Phillip J. \\ Wright, ${ }^{\text {a Jean-Philippe Crouéa,e }}{ }^{\text {and Sébastien Allard }}{ }^{a}$
}

\begin{abstract}
Pre-oxidation is commonly used to mitigate the formation of byproducts during post-disinfection. A comparative study of the impact of four pre-oxidants, ozone $\left(\mathrm{O}_{3}\right)$, chlorine dioxide $\left(\mathrm{ClO}_{2}\right)$, permanganate $(\mathrm{Mn}(\mathrm{VII}))$ and ferrate $(\mathrm{Fe}(\mathrm{VI}))$, on the formation of trihalomethanes (THMs), haloacetonitriles (HANs) and adsordable organic halogens (AOX) in chlorinated synthetic and real waters was conducted. The pre-oxidant doses were based on their impact on natural organic matter reactivity measured by the electron donating capacity before chlorination. The influence of $\mathrm{pH}(6.5-8.1)$ and bromide (0$500 \mu \mathrm{g} \mathrm{L}^{-1}$ ) was evaluated in terms of disinfection byproduct (DBP) formation and theoretical toxicity assessment (based on THM and HAN formation). All oxidants were efficient in mitigating chlorinated DBPs, except Mn(VII) which had little impact on THM formation. $\mathrm{O}_{3}$ was generally more efficient than the other oxidants in mitigating AOX and THM formation, all pre-oxidants were readily reducing the formation of $\mathrm{HANs}$ ( $>45 \%$ reduction at high dose). $\mathrm{pH}$ depression improved $\mathrm{AOX}$ mitigation by $\mathrm{O}_{3}$ and $\mathrm{Fe}(\mathrm{VI})$ but diminished $\mathrm{Mn}(\mathrm{VII})$ efficiency for all DBPs. Pre-oxidation was less efficient in mitigating brominated DBPs and generally enhanced the bromine substitution factor. Although HANs were formed at low concentrations compared to THMs, they dominated the calculated toxicity, particularly the brominated HANs. The increased dibromoacetonitrile formation after pre-oxidation was a major factor counteracting the benefit of the overall DBP mitigation. In presence of bromide, the pre-oxidant dose should be optimized to decrease the reactivity of the matrix while controlling the toxicity induced by formation of brominated DBPs, notably the brominated HANs.
\end{abstract}

\section{Introduction}

Chlorine is worldwide the most widely used disinfectant in drinking water treatment. However, the formation of disinfection byproducts (DBPs) has been an on-going problem of concern. ${ }^{1}$ Pre-oxidation has been successfully applied to reduce the formation of DBPs during post-chlorination. ${ }^{2-4}$ Potential pre-oxidants such as ozone $\left(\mathrm{O}_{3}\right)$, ferrate $(\mathrm{Fe}(\mathrm{VI}))$ or permanganate $(\mathrm{Mn}(\mathrm{VII}))$ are chlorine-free, and therefore are not producing chlorinated DBPs (Cl-DBPs) while degrading their precursors. ${ }^{2,3}$ Chlorine dioxide $\left(\mathrm{ClO}_{2}\right)$ is not directly able to

\footnotetext{
a. School of Molecular and Life Sciences (MLS), Curtin University, GPO Box U1987, 6845 Perth, Western Australia, Australia.

b. Eawag, Swiss Federal Institute of Aquatic Science and Technology, $\mathrm{CH}-8600$ Dübendorf, Switzerland

School of Architecture, Civil and Environmental Engineering (ENAC), Ecole Polytechnique Fédérale Lausanne (EPFL), CH-1015 Lausanne, Switzerland

d. ETH Zurich, Swiss Federal Institute of Technology, Institute of Biogeochemistry and Pollutant Dynamics (IBP), Department of Environment Systems (D-USYS), Universitätstrasse 16, $\mathrm{CH}-8092$ Zürich

e. Institut de Chimie des Milieux et des Matériaux IC2MP UMR 7285 CNRS, Université de Poitiers, France
}

+ Current address: School of Earth Sciences and Environmental Engineering, Gwangju Institute of Science and Technology (GIST), Gwangju 61005, Republic of Korea.

Electronic Supplementary Information (ESI) available: [details of any supplementary information available should be included here]. See DOI: 10.1039/x0xx00000x halogenate natural organic matter (NOM) but was recently shown to produce chlorine in situ, which can in turn form Cl-DBPs. ${ }^{5,} 6$ Nonetheless, the formation of halogenated DBPs after $\mathrm{ClO}_{2}$ treatment is much lower compared to chlorination. Together with the reduction of the water matrix reactivity, the use of pre-oxidation can have complementary benefits such as a degradation of contaminants, ${ }^{7,8}$ disinfection (except for $\mathrm{Mn}(\mathrm{VII}))^{9,}, 10$ or coagulation. ${ }^{10-12}$

DBP reduction has been achieved by pre-oxidizing various water matrices with $\mathrm{ClO}_{2}, 4,13,14 \mathrm{O}_{3}, 2,15,16 \mathrm{Fe}(\mathrm{VI}),{ }^{14,}, 17-19$ and $\mathrm{Mn}(\mathrm{VII}){ }^{18,} 20$ However, only a few studies compared the efficiency of different pre-oxidants. In a previous study $\mathrm{ClO}_{2}$ and $\mathrm{Fe}(\mathrm{VI})$ efficiency on DBP formation during chlorination of 12 waters has been compared. ${ }^{14}$ It was found that $20 \mathrm{mgFe} \mathrm{L}^{-1}$ as $\mathrm{Fe}(\mathrm{VI})$ was more efficient to mitigate $\mathrm{HAN}$ formation and less efficient for THM mitigation compared to $1 \mathrm{mg} \mathrm{L}^{-1}$ of $\mathrm{ClO}_{2}$. Even though there are effects of both oxidants on DBPs, the very different doses don't allow a direct comparison (see discussion below). In two other comparative studies, equivalent mass concentrations of $\mathrm{Fe}(\mathrm{VI})$ and $\mathrm{O}_{3}$ gave similar THM, haloacetic acid and HAN abatement in different real waters. ${ }^{3,}{ }^{21}$ Another study showed a generally better DBP abatement by $\mathrm{Fe}(\mathrm{VI})$ preoxidation compared to $\mathrm{Mn}(\mathrm{VII})$ pre-oxidation, based on equivalent mass concentrations. ${ }^{18}$ The reactivity of the water matrix (described by dissolved organic carbon, DOC, and UV absorbance at $254 \mathrm{~nm}, \mathrm{UVA}_{254}$ ), the $\mathrm{pH}$ as well as the presence 
of halide ions such as bromide or iodide will impact the formation of DBPs and their mitigation. ${ }^{22-24}$ For instance, the presence of bromide leads to the formation of brominated DBPs (Br-DBPs) during chlorination, ${ }^{22}$ which are generally more toxic than their chlorinated analogues. ${ }^{25}$ Applying $\mathrm{ClO}_{2}$ and $\mathrm{O}_{3}$ pre-oxidation has been shown to impact the speciation of DBPs in bromide-containing waters. ${ }^{2,13,15,16,26}$ Furthermore, the fate of bromide during pre-oxidation also needs to be considered. $\mathrm{O}_{3}$ is known to moderately react with bromide to form bromine $\left(\mathrm{HOBr} / \mathrm{OBr}^{-}\right)$, leading to the formation of organic Br-DBPs and potentially bromate. ${ }^{27}$ However, $\mathrm{HOBr}$ is in competition with $\mathrm{O}_{3}$ for some highly reactive NOM moieties. ${ }^{26}$ Therefore, the formation of $\mathrm{Br}$-DBPs and bromate depends on the $\mathrm{O}_{3}$ and hydroxyl radical exposure, the bromide concentration and the NOM characteristics. $\mathrm{ClO}_{2}$ is unreactive toward bromide, ${ }^{28}$ but may form $\mathrm{HOBr}$ through the in situ formation of chlorine $\left(\mathrm{HOCl} / \mathrm{OCl}^{-}\right),{ }^{5,6}$ while $\mathrm{Fe}(\mathrm{VI})$ was recently shown to slowly react with bromide, leading to $\mathrm{HOBr}$ and bromate in absence of phosphate. ${ }^{29}$ The $\mathrm{pH}$ is also an important parameter affecting the formation and the speciation of DBPs during chlorination. ${ }^{22}$ Typically, increasing the $\mathrm{pH}$ will enhance the formation of trihalomethanes (THMs) and lowering the $\mathrm{pH}$ will lead to higher haloacetonitriles (HANs) concentrations. ${ }^{30,31}$ The $\mathrm{pH}$ may also impact the stability of the pre-oxidants. $\mathrm{O}_{3}$ and $\mathrm{Fe}(\mathrm{VI})$ are known to self-decompose in water. The self-decays of $\mathrm{O}_{3}$ (and concomitant hydroxyl radical formation) and $\mathrm{Fe}(\mathrm{VI})$ increases or decreases, respectively, with increasing $\mathrm{pH}^{32,} 33$ In comparison, $\mathrm{ClO}_{2}$ and $\mathrm{Mn}(\mathrm{VII})$ are stable across the $\mathrm{pH}$ range relevant to water treatment. ${ }^{34}$ The reactivity of the pre-oxidants toward DBP precursors will also be affected by $\mathrm{pH}$. For instance, the reactivity of phenol toward $\mathrm{Fe}(\mathrm{VI})$ tends to decrease with increasing $\mathrm{pH}$ while it increases with $\mathrm{Mn}(\mathrm{VII}), \mathrm{O}_{3}$ and $\mathrm{ClO}_{2}$. $7,28,35$, ${ }^{36}$ Furthermore, the reaction or degradation products of $\mathrm{O}_{3}$, $\mathrm{ClO}_{2}, \mathrm{Mn}(\mathrm{VII})$ and $\mathrm{Fe}(\mathrm{VI})$ can participate in the overall oxidation processes. $5,32,37,38$

It is challenging to make general conclusions on the impact of pre-oxidation treatment on DBP formation due to the variability of experimental conditions across studies. Furthermore, supplementary treatments after pre-oxidation, such as coagulation, (biological) activated carbon or sand filtration, are likely to affect the NOM characteristics and therefore the formation of DBPs during subsequent chlorination. ${ }^{17,}{ }^{39-41}$ In previous studies, the choice of the pre-oxidant doses has usually been based on molar concentrations, mass concentrations or doses commonly used in drinking water treatment plants. Recently, it was proposed to compare the efficiency of pre-oxidants based on their impact on NOM characteristics. ${ }^{42}$ The recently introduced electron donating capacity (EDC) is a proxy for activated aromatic compounds, ${ }^{43}, 44$ generally decreasing more readily than the UVA $_{254}$ upon oxidative treatments. ${ }^{42,}{ }^{45,} 46$ Therefore, it is an interesting surrogate to monitor changes in NOM characteristics related to oxidative treatment.

In this study, a comparison of the impacts of four pre-oxidants, i.e., $\mathrm{ClO}_{2}, \mathrm{O}_{3}, \mathrm{Fe}(\mathrm{VI})$ and $\mathrm{Mn}(\mathrm{VII})$, on the formation of AOX, THMs and HANs during post-chlorination is presented. The impact of the pre-oxidation treatments is presented based on doses of oxidants inducing equivalent effects on the EDC of NOM. The impact of pre-oxidant dose, bromide concentration and $\mathrm{pH}$ on the reduction of the concentration and the speciation of DBPs is evaluated. The benefits of pre-oxidation are also discussed in terms of calculated toxicity, based on THM and HAN formation. This study does not aim to reproduce real water treatment conditions since no coagulation or (bio)filtration step was applied after pre-oxidation.

\section{Materials and methods}

\subsection{Chemicals and reagents.}

Sodium chlorite (80\%) and a sodium hypochlorite solution (10$15 \%)$ were purchased from Sigma Aldrich. The impurities in the sodium chlorite and sodium hypochlorite were mostly chloride and traces of chlorate $\left(<0.01 \mu \mathrm{M}\right.$ of $\mathrm{ClO}_{3}{ }^{-}$per $\mu \mathrm{M}$ of $\mathrm{NaOCl}$ or $\mathrm{NaClO}_{2}$ ). All other chemicals were of analytical grade purity $(\geq 98 \%)$. Solutions were prepared with ultrapure water (Purelab Ultra, Elga, UK). Suwannee River NOM extract was purchased from the International Humic Substances Society (Cat. No. 2R101N).

\subsection{Preparation of oxidant solutions.}

Chlorine stock solutions were prepared from a sodium hypochlorite solution standardized by direct UV measurement at $292 \mathrm{~nm}\left(\varepsilon_{292}=362 \mathrm{M}^{-1} \mathrm{~cm}^{-1}\right) \cdot{ }^{47} \mathrm{~A} \mathrm{ClO}_{2}$ stock solution was produced by reaction of sodium persulfate $\left(40 \mathrm{~g} \mathrm{~L}^{-1}\right)$ and sodium chlorite $\left(80 \mathrm{~g} \mathrm{~L}^{-1}\right)$ under nitrogen bubbling for about $1 \mathrm{~h}{ }^{48,49}$ The $\mathrm{ClO}_{2}$ was retrieved in chilled ultrapure water $\left(\mathrm{T}<10^{\circ} \mathrm{C}\right)$ and standardized by direct UV measurement at $359 \mathrm{~nm}$ $\left(\varepsilon_{359}=1230 \mathrm{M}^{-1} \mathrm{~cm}^{-1}\right) \cdot{ }^{47} \mathrm{An} \mathrm{O}_{3}$ stock solution was prepared by bubbling an ozone-oxygen gas mixture produced by an ozone generator (American Ozone System Inc.) in chilled ultrapure water $\left(\mathrm{T}<5^{\circ} \mathrm{C}\right)$. The $\mathrm{O}_{3}$ stock solution $(0.6-0.9 \mathrm{mM})$ was standardized by direct UV measurement at $260 \mathrm{~nm}$ $\left(\varepsilon_{260}=3200 \mathrm{M}^{-1} \mathrm{~cm}^{-1}\right) \cdot{ }^{32}$ Potassium ferrate $\left(\mathrm{K}_{2} \mathrm{FeO}_{4}\right)$ was prepared by oxidation of $0.186 \mathrm{~mol}$ of ferric nitrate nonahydrate with $0.845 \mathrm{~mol}$ of potassium hypochlorite in a concentrated potassium hydroxide solution. ${ }^{50}$ The final product purity was $43 \%$ and was stable over the duration of this study. The rest of the solid was potassium hydroxide or potassium chloride. $\mathrm{Mn}(\mathrm{VII})$ and $\mathrm{Fe}(\mathrm{VI})$ solutions were prepared by dissolution of $\mathrm{KMnO}_{4}$ in ultrapure water for $\mathrm{Mn}(\mathrm{VII})$, or of $\mathrm{K}_{2} \mathrm{FeO}_{4}$ in a phosphate/borate buffer at $\mathrm{pH} 9.5(5 \mathrm{mM} / 1 \mathrm{mM})$ for $\mathrm{Fe}(\mathrm{VI})$. The stock solutions (1-5 mM) were filtered through $0.22 \mu \mathrm{m}$ (Polyethersulfone, Merck Millipore) and standardized by direct UV measurements at $525 \mathrm{~nm}\left(\varepsilon_{525}=2430 \mathrm{M}^{-1} \mathrm{~cm}^{-1}\right)^{51}$ for $\mathrm{Mn}(\mathrm{VII})$ or $510 \mathrm{~nm}\left(\varepsilon_{510}=1150 \mathrm{M}^{-1} \mathrm{~cm}^{-1}\right)^{52}$ for $\mathrm{Fe}(\mathrm{VI})$.

\subsection{Pre-oxidation and chlorination experiments.}

The synthetic waters were prepared with $3.0 \mathrm{mgC} \mathrm{L}^{-1}$ of a Suwannee River NOM extract (SRNOM) buffered at $\mathrm{pH} 6.5$ ( $40 \mathrm{mM}$ phosphate) or $\mathrm{pH} 8$ ( $40 \mathrm{mM}$ borate) with or without bromide $\left(0,150\right.$ or $\left.500 \mu \mathrm{g} \mathrm{L}^{-1}\right)$. The synthetic waters $(500 \mathrm{~mL})$ were spiked with $\mathrm{O}_{3}$ (with $5 \mathrm{mM}$ of tert-butanol, $t-\mathrm{BuOH}$ ), $\mathrm{ClO}_{2}$, $\mathrm{KMnO}_{4}$ or $\mathrm{K}_{2} \mathrm{FeO}_{4}(1-94.3 \mu \mathrm{M}$, Table 1), kept without headspace 
( $<10 \%$ of total volume) and protected from light until complete depletion of the oxidants. For medium and high $\mathrm{O}_{3}$ doses, the significant volume of $\mathrm{O}_{3}$ stock solution added was taken into account by concentrating the matrix accordingly. $t$ - $\mathrm{BuOH}$ was added as a hydroxyl radical scavenger to account for direct $\mathrm{O}_{3}$ reactions only, at a dose based on a previous study. ${ }^{45}$ All the samples were then filtered through $0.22 \mu \mathrm{m}$ (Polyethersulfone, Merck Millipore). Around $200 \mathrm{~mL}$ of the sample was used for the analyses of electron donating capacity (EDC), anions (bromide, bromate, chlorite and chlorate), AOX, THMs and HANs, and $200 \mathrm{~mL}$ was chlorinated with $85 \mu \mathrm{M}$ of sodium hypochlorite $\left(6.0 \mathrm{mgCl}_{2} \mathrm{~L}^{-1}\right)$ for $72 \mathrm{~h}$, without headspace $(<10 \%$ of total volume) and protected from light. The chlorine dose was sufficient to ensure an oxidant residual of at least $1.4 \mathrm{mgCl}_{2} \mathrm{~L}^{-1}$ after $72 \mathrm{~h}$ at $\mathrm{pH} \mathrm{8}$, without bromide and without pre-treatment. The oxidant residual was quenched by sodium sulfite ( $10 \%$ molar excess relative to the chlorine residual) for AOX, bromide and bromate measurements, or by a 5 times molar excess (relative to the chlorine residual) of ascorbic acid for THMs and HANs. All experiments with SRNOM were duplicated, except for the highest doses of $\mathrm{Fe}(\mathrm{VI})$ and $\mathrm{Mn}(\mathrm{VII})$. A similar experiment was conducted with water from a shallow groundwater (W20) with 10-30 $\mu \mathrm{M}$ pre-oxidant (Table 1) and $155 \mu \mathrm{M}$ chlorine $\left(12.4 \mathrm{mgCl}_{2} \mathrm{~L}^{-1}\right)$. The chlorine dose was chosen based on a chlorine demand experiment allowing a chlorine residual of about $1.5 \mathrm{mgCl}_{2} \mathrm{~L}^{-1}$ after $72 \mathrm{~h}$. The main characteristics of the real and synthetic waters are given in Table 2.

\subsection{Analytical methods.}

THMs (trichloro-, bromodichloro-, dibromochloro- and tribromomethane) and HANs (chloro-, bromo-, dichloro-, bromochloro-, dibromo- and trichloroacetonitrile) were analyzed by headspace GC-MS with a method adapted from a previous publication (details are given in Text S1). ${ }^{53,} 54$ Abbreviations used for individual THMs and HANs are shown in Table S1 (Electronic Supporting Information, ESI). The AOX was measured by ion chromatography after combustion of the activated carbon with the adsorbed samples. ${ }^{55}$ The limit of quantification (LOQ) for $\mathrm{AOCl}$ and $\mathrm{AOBr}$ were $0.5 \mu \mathrm{M}$ (as $\mathrm{Cl}^{-}$) and $0.1 \mu \mathrm{M}$ (as $\mathrm{Br}^{-}$), respectively. Standard deviations for $\mathrm{AOCl}$ and $\mathrm{AOBr}$ typically ranged between $5-15 \%$. The chlorine residual was measured by ABTS (2,2'-azino-bis(3-ethylbenzothiazolinesulfonic acid) diammonium salt). ${ }^{56}$ Bromide (LOQ $\left.=0.05 \mu \mathrm{M}\right)$, bromate $(\mathrm{LOQ}=0.02 \mu \mathrm{M})$, chlorite $(\mathrm{LOQ}=0.08 \mu \mathrm{M})$ and chlorate $(\mathrm{LOQ}=0.06 \mu \mathrm{M})$ were measured by ion chromatography using an AS10-HC column with a $\mathrm{Na}_{2} \mathrm{CO}_{3}$ eluent $\left(9 \mathrm{mM}, 1 \mathrm{~mL} \mathrm{~min}{ }^{-1}\right) .{ }^{57}$ The electron donating capacity (EDC), a proxy for antioxidant capacity of $\mathrm{NOM}^{43,45}$ was measured on an Agilent 1100 series system using a sizeexclusion chromatography (SEC) followed by a post-column reaction with the ABTS radical. This method was adapted from previous studies, ${ }^{58,59}$ and is described elsewhere. ${ }^{42}$ The EDC is presented as percentage of reduction compared to the untreated sample, or relative to a $3 \mathrm{mgC} \mathrm{L}^{-1}$ unbuffered SRNOM sample.

\section{Results and discussion}

\subsection{Impact of pre-oxidation on the EDC of SRNOM.}

Different pre-oxidant doses were spiked to solutions containing $3 \mathrm{mgC} \mathrm{L}^{-1}$ of SRNOM. Three doses were applied, low, medium and high, corresponding to an approximate relative EDC abatement of 20,50 and $70 \%$ at $\mathrm{pH} 8$, respectively (Table 1 ). As previously observed, very low doses of $\mathrm{Mn}(\mathrm{VII})$ led to large relative EDC abatements, ${ }^{42}$ resulting in inaccuracies for the low dose experiment. Therefore, only medium and high doses of $\mathrm{Mn}(\mathrm{VII})$ were applied in this study.

\subsection{DBP formation after pre-oxidation.}

After pre-oxidation and in absence of bromide, only $\mathrm{ClO}_{2}$ produced low concentrations of $\mathrm{Cl}$-DBPs through the in situ formation of hypochlorous acid ( $\mathrm{HOCl}$ ) (Figs. S1a,b, Electronic Supporting Information, ESI). ${ }^{5,6} \mathrm{~A}$ maximum of $2.1 \pm 0.8 \mu \mathrm{M}$ of $\mathrm{AOCl}$ and $10 \pm 0.7 \mathrm{nM}$ of trichloromethane (TCM) were formed, consistent with a previous study. ${ }^{5}$ Along with organic DBPs, up to $25 \mu \mathrm{M}$ of chlorite $\left(1.7 \mathrm{mg} \mathrm{L}^{-1}\right)$ and up to $2.7 \mu \mathrm{M}$ of chlorate (0.2 $\mathrm{mg} \mathrm{L}^{-1}$ ) were formed after $\mathrm{ClO}_{2}$ pre-oxidation (Fig. S2, ESI).

In presence of bromide, both $\mathrm{ClO}_{2}$ (through the in situ formation of $\mathrm{HOCl}$ ) and $\mathrm{O}_{3}-t-\mathrm{BuOH}$ (through direct oxidation of bromide to $\mathrm{HOBr}$ ) formed $\mathrm{Br}$-DBPs. As a result, a significant decrease of bromide (7-22\%) was observed after pre-oxidation at high doses of $\mathrm{ClO}_{2}$ and $\mathrm{O}_{3}-t-\mathrm{BuOH}$ (Fig. S3, ESI). Consequently, up to $1.8 \pm 0.3 \mu \mathrm{M}$ and $1.1 \pm 0.1 \mu \mathrm{M}$ of $\mathrm{AOBr}$ was formed after pre-oxidation with high doses of $\mathrm{ClO}_{2}$ and $\mathrm{O}_{3}-t-\mathrm{BuOH}$, respectively (Figs. S1a,c, ESI). Traces of all four THMs were produced after $\mathrm{ClO}_{2}$ pre-oxidation (total THMs $<10 \mathrm{nM}$ ) while only tribromomethane (TBM) was formed at high dose of $\mathrm{O}_{3}-t$ BuOH (up to $69 \pm 11 \mathrm{nM}$ ) (Figs. S1b,d, ESI).

The bromide concentration was not decreasing after Fe(VI) and $\mathrm{Mn}(\mathrm{VII})$ pre-oxidation ( $<5 \%$ decrease, Fig. S3, ESI) and consequently no Br-DBPs were formed. ${ }^{29}$ No bromate $(<3 \mathrm{nM})$ was detected after $\mathrm{O}_{3}-t-\mathrm{BuOH}$ and $\mathrm{Fe}(\mathrm{VI})$ pre-oxidation. As mentioned in the introduction, $\mathrm{Fe}(\mathrm{VI})$ slowly reacts with bromide. ${ }^{29}$ In borate buffer at $\mathrm{pH} 7.5$ and without NOM, $50 \mu \mathrm{M}$ of $\mathrm{Fe}(\mathrm{VI})$ oxidizes only about $5 \%$ of bromide. ${ }^{29}$ Both a higher $\mathrm{pH}$ and the presence of NOM are likely mitigating the oxidation of bromide by $\mathrm{Fe}(\mathrm{VI})$, which is consistent with the apparent lack of reactivity between bromide and $\mathrm{Fe}(\mathrm{VI})$ (Fig. S3, ESI) and with the lack of formation of Br-DBPs or bromate.

\subsection{Pre-oxidation efficiency on DBP mitigation during final chlorination of SRNOM in absence of bromide.}

\subsubsection{Chlorination alone.}

Without pre-oxidation and in absence of bromide, $16.6 \pm 1.5 \mu \mathrm{M}$ of $\mathrm{AOCl}$ (Fig. 1a), $2.8 \pm 0.3 \mu \mathrm{M}$ of THMs (TCM only, Fig. 1d) and $50 \pm 8 \mathrm{nM}$ of HANs (95\% dichloroacetonitrile (DCAN) and $5 \%$ trichloroacetonitrile (TCAN), Fig. 1g) were formed after $72 \mathrm{~h}$ of chlorination of SRNOM. These results are consistent with a previous study carried out with a $3 \mathrm{mgC} \mathrm{L}^{-1}$ Suwannee River Fulvic Acids extract, which produced $16 \mu \mathrm{M}$ and $2.5 \mu \mathrm{M}$ of $\mathrm{AOCl}$ and TCM, respectively, after 5 days of chlorination at $\mathrm{pH} 7.5 .{ }^{60}$ In the previous study, HANs were not 
detected, probably because of the longer reaction time, promoting HAN hydrolysis. ${ }^{30}$

\subsubsection{Pre-oxidation followed by chlorination.}

When pre-oxidation was applied, the formation of AOCl, TCM and HANs were mitigated to various extents (Figs. 1a, d, g). The mitigation generally increased with increasing pre-oxidant doses. For the highest pre-oxidant dose, $\mathrm{AOCl}$ formation was reduced by $30 \pm 3 \%, 53 \pm 5 \%, 21 \pm 2 \%$ and $20 \pm 2 \%$ for $\mathrm{ClO}_{2}, \mathrm{O}_{3}-t$ $\mathrm{BuOH}, \mathrm{Fe}(\mathrm{VI})$ and $\mathrm{Mn}(\mathrm{VII})$, respectively, compared to chlorination alone (Fig. 1a). It was previously shown that for a similar EDC abatement, an equivalent AOX mitigation was obtained for $\mathrm{ClO}_{2}, \mathrm{Fe}(\mathrm{VI})$ and $\mathrm{Mn}(\mathrm{VII}){ }^{42}$ The slightly higher mitigation of $\mathrm{AOCl}$ observed for $\mathrm{ClO}_{2}$ compared to $\mathrm{Fe}(\mathrm{VI})$ and $\mathrm{Mn}(\mathrm{VII})$ could be explained by the slightly higher EDC abatement (77\% versus $68-69 \%$, Table 1 ). In comparison, $\mathrm{O}_{3}-\mathrm{t}$ $\mathrm{BuOH}$ was more efficient to mitigate AOX than the other pre-oxidants probably due to Criegee-type reactions which lead to aromatic ring cleavage, resulting in a reduction of halogenation reactions (Fig. 1a). ${ }^{61,62}$

High doses of $\mathrm{ClO}_{2}, \mathrm{O}_{3}-\mathrm{t}-\mathrm{BuOH}$ and $\mathrm{Fe}(\mathrm{VI})$ also reduced THM formation by $29 \pm 3 \%, 30 \pm 1 \%$ and $26 \pm 3 \%$, respectively (Fig. 1d). In contrast, $\mathrm{Mn}$ (VII) was not efficient in mitigating THM formation ( $\leq 10 \%$ ), which is consistent with previous studies. ${ }^{18}$, $20,40,63$ While the THMs represented $49-54 \%$ of the AOX (in moles of halogen) in samples without pre-treatment, this fraction was substantially increased by $\mathrm{O}_{3}-\mathrm{t}-\mathrm{BuOH}$ (up to $74 \%$ ) and $\mathrm{Mn}\left(\mathrm{VII}\right.$ ) (up to $62 \%$ ) while it remained unaffected by $\mathrm{ClO}_{2}$ (47-55\%) and $\mathrm{Fe}(\mathrm{VI})(42-50 \%)$ (Fig. S4, ESI). This increase in the THM fraction may be explained by a transformation of activated aromatic compounds to aliphatic $\beta$-keto-acid and $\beta$-diketone structures which lead to less halogenation but a higher yield of THMs compared to phenol. ${ }^{61}$

In comparison to the AOX and THMs, the HAN formation was much more efficiently mitigated by all oxidants with $66 \pm$ $4 \%, 68 \pm 7 \%, 45 \pm 4 \%$ and $53 \pm 12 \%$ reduction of their formation at high doses of $\mathrm{ClO}_{2}, \mathrm{O}_{3}-t-\mathrm{BuOH}, \mathrm{Fe}(\mathrm{VI})$ and $\mathrm{Mn}(\mathrm{VII})$, respectively (Fig. $1 \mathrm{~g}$ ). A generally efficient HAN mitigation by pre-oxidation has been previously observed by all four oxidants. ${ }^{13,14,16,18,21}$

\subsection{Pre-oxidation efficiency on DBP mitigation during final chlorination of SRNOM: impact of bromide.}

\subsubsection{Total DBPs.}

During chlorination in presence of 150 or $500 \mu \mathrm{g} \mathrm{L}^{-1}$ bromide and without pre-oxidation, $15.8 \pm 1.5 \mu \mathrm{M}$ and $15.6 \pm 1.6 \mu \mathrm{M}$ of AOX were produced, respectively, which was not significantly different from the AOX formation without bromide (Figs. 1a-c). Similarly, the total THM $(2.8-2.9 \pm 0.4 \mu \mathrm{M})$ and the total HAN (50-59 $\pm 9-18 \mathrm{nM})$ formations in presence of bromide were not significantly different from the sample without bromide (Figs. $1 d-f$ and Figs. $1 g-i$ ). The AOX and THM formation was consistent with a previous study using a Suwannee River Fulvic Acid extract ( $3 \mathrm{mgC} \mathrm{L}^{-1}$ ) in presence of $104 \mathrm{\mu g} \mathrm{L}^{-1}$ bromide, where $16.1 \mu \mathrm{M}$ of AOX and $2.0 \mu \mathrm{M}$ of THMs were found. ${ }^{60}$
The pre-oxidation efficiency on the total formation of AOX, THMs and HANs was generally reduced by the presence of bromide as illustrated in Fig. 2 and Fig. S5 (ESI) (DBP mitigation relative to the experiment without pre-oxidation). At the highest doses of $\mathrm{ClO}_{2}, \mathrm{O}_{3}-\mathrm{t}-\mathrm{BuOH}$ and $\mathrm{Mn}(\mathrm{VII})$, the addition of $500 \mu \mathrm{g} \mathrm{L}^{-1}$ bromide decreased the HAN mitigation efficiency from $66 \pm 4 \%, 68 \pm 7 \%$ and $53 \pm 12 \%$ without bromide to $42 \pm$ $7 \%, 63 \pm 26 \%$ and $14 \pm 5 \%$, respectively (Fig. 2). Similarly, AOX mitigation decreased from $30 \pm 3 \%, 53 \pm 5 \%$ and $20 \pm 2 \%$ to 23 $\pm 3 \%, 42 \pm 9 \%$ and $16 \pm 1 \%$, in presence of $500 \mathrm{\mu g} \mathrm{L}^{-1}$ bromide, at the highest doses of $\mathrm{ClO}_{2}, \mathrm{O}_{3}-t-\mathrm{BuOH}$ and $\mathrm{Mn}(\mathrm{VII})$, respectively (Fig. S5a, ESI). For THMs, the addition of $500 \mu \mathrm{g} \mathrm{L}^{-1}$ bromide led to a decrease of the mitigation efficiency from $29 \pm 3 \%, 30 \pm 1 \%$ and $26 \pm 3 \%$ to $25 \pm 3 \%, 14 \pm 2 \%$ and $3 \pm 1 \%$ at the highest doses of $\mathrm{ClO}_{2}, \mathrm{O}_{3}-\mathrm{t}-\mathrm{BuOH}$ and $\mathrm{Fe}(\mathrm{VI})$, respectively (Fig. S5b, ESI).

Conversely to the general trend, the experiment carried out with $\mathrm{Fe}(\mathrm{VI})$ and $500 \mu \mathrm{g} \mathrm{L}^{-1}$ bromide showed an improved mitigation of AOX (Fig. S5a, ESI). However, the presence of $150 \mu \mathrm{g} \mathrm{L}^{-1}$ bromide still decreased the AOX mitigation efficiency (Fig. S5a, ESI).

\subsubsection{DBP Speciation.}

Although the total DBP concentration was not affected by the presence of bromide in samples without pre-oxidation of SRNOM, Br-DBPs were formed. At 150 and $500 \mu \mathrm{g} \mathrm{L}^{-1}$ bromide, $1.6 \pm 0.1$ and $5.8 \pm 0.3 \mu \mathrm{M}$ of $\mathrm{AOBr}$ were produced, respectively, representing $85-93 \pm 5 \%$ of the initial bromide (Figs. 1b,c). About half of the bromide (49-57\%) was recovered in THMs as TBM, dibromochloromethane (DBCM) and dichlorobromomethane (DCBM) (Figs. 1e,f), while $0.7-1.2 \%$ was incorporated in the HANs as dibromoacetonitrile (DBAN) and bromochloroacetonitrile (BCAN) (Figs. 1h,i). Increasing the bromide concentration increased the bromine substitution factor (BSF). The BSF is the fraction of bromine relative to the total halogens of a specific group of DBPs, ${ }^{64}$ and is calculated as follows (eq. 1):

$$
B S F=\frac{[B r-D B P s]}{[X-D B P s]} \times 100
$$

Without pre-oxidation, the addition of $150 \mathrm{\mu g} \mathrm{L}^{-1}$ bromide led to a BSF of $11 \pm 1 \%, 12 \pm 0.5 \%$ and $13 \pm 3 \%$ in AOX, THMs and HANs, respectively (Fig. 3). Increasing the bromide concentration to $500 \mathrm{\mu g} \mathrm{L}^{-1}$ increased the BSF in AOX, THMs and HANs to $39 \pm 2 \%, 38 \pm 2 \%$ and $51 \pm 25 \%$, respectively (Fig. S6, ESI). Interestingly, the BSF for HAN increased to a higher extent than for the AOX or the THM when increasing the bromide concentration. A higher stability of brominated HANs compared to their chlorinated analogues may partly explain this trend. ${ }^{30}$

Overall, the pre-oxidation more efficiently mitigated the Cl-DBPs than the Br-DBPs (Figs. 3 and S5, ESI), consistent with previous studies. ${ }^{13,21}$ For example an increase of BSF following the order $\mathrm{O}_{3}-\mathrm{t}$ - $\mathrm{BuOH}(+11 \%)>\mathrm{ClO}_{2} / \mathrm{Fe}(\mathrm{VI})(+5 \%)>\mathrm{Mn}(\mathrm{VII})(+$ 2\%) for THMs and $150 \mu \mathrm{g} \mathrm{L}^{-1}$ bromide was observed (Fig. 3b). The only exception was a reduction of the BSF by $\mathrm{Mn}(\mathrm{VII})$ for the HANs at $150 \mu \mathrm{g} \mathrm{L}^{-1}$ bromide (Fig. 3c), although the variations of the data were high. While the $\mathrm{AOBr}$ formation was not significantly impacted by any pre-oxidant at 150 or $500 \mu \mathrm{g} \mathrm{L}^{-1}$ 
bromide ( $\leq 10 \%$ mitigation, Figs. $1 b, c)$, pre-oxidation could enhance the concentration of brominated THMs and HANs. At $150 \mu \mathrm{g} \mathrm{L}^{-1}$ bromide, the sum of BDCM and DBCM concentrations increased with increasing dose for all the pre-oxidants (Fig. 1e). For $500 \mu \mathrm{g} \mathrm{L}^{-1}$ bromide, a similar trend was observed for DBCM and TBM concentrations (Fig. 1f). For the HANs, the main increase in concentration was observed for DBAN upon preoxidation (Figs. 1h, i). More specifically, the mitigation efficiency of a specific DBP was anticorrelated to the number of bromine atoms in the compound. In presence of $500 \mathrm{~g} \mathrm{~L}^{-1}$ bromide, TCM and DCBM were mitigated by $19-85 \%$ and $8-37 \%$, respectively, while DBCM and TBM concentrations were enhanced by $4-12 \%$ ( $\mathrm{Mn}$ (VII) was still mitigating DBCM formation by $5 \%$ ) and $7-$ $195 \%$, respectively (Fig. 4, THM mitigation is calculated based on the experiment without pre-oxidation). Similar patterns were observed for the THMs at $150 \mu \mathrm{g} \mathrm{L}^{-1}$ bromide (Fig. S7, ESI) and with HANs (Fig. S8, ESI).

\subsubsection{Discussion.}

In presence of chlorine, bromide is rapidly oxidized to $\mathrm{HOBr}, 65$ which in turn reacts with NOM 1-2 orders of magnitude faster than chlorine. ${ }^{66}$ About $20 \%$ of the $\mathrm{HOBr}$ will react through electrophilic aromatic substitutions, i.e., forming $\mathrm{AOBr}$, while the rest will be reduced back to bromide via electron transfer reactions. ${ }^{67}$ When pre-oxidation was applied, the decrease of $\mathrm{AOCl}$ and the limited impact observed on $\mathrm{AOBr}$ can be explained by four factors. (i) A reduction of the number of HOX-reactive sites. (ii) An excess of NOM sites reactive with $\mathrm{HOX}(\mathrm{HOCl}$ or $\mathrm{HOBr}$ ) after pre-oxidation treatment relative to the available $\mathrm{HOBr}$. (iii) A re-oxidation of the bromide released in solution after electron transfer reactions by the excess chlorine until its complete incorporation in NOM. ${ }^{23}$ (iv) A faster reaction of $\mathrm{HOBr}$ with NOM moieties compared to $\mathrm{HOCl} .{ }^{66,} 68$ Therefore, even after pre-oxidation, bromine was fully incorporated in NOM while the remaining fraction of AOX precursors available to react with the excess of $\mathrm{HOCl}$ was limited, leading to a mitigation of $\mathrm{AOCl}$ (Figs. 1b-c). Furthermore, it was previously shown that bromine could substitute chlorine, which is already incorporated in NOM. ${ }^{23}$

The decrease of reactive sites after pre-oxidation also favoured multiple bromination of the same site and the formation of di- and tri-Br-DBPs (Figs. 1e,f,h,l and Fig. 4). In contrast, the pre-oxidation did not enhance multiple chlorination since an excess of chlorine and a long reaction time already ensured multiple halogenation with or without pre-oxidation. Overall, for chlorine, the number of reactive sites is restrained, leading to a limited concentration of chlorinated DBPs.

\subsection{Pre-oxidation efficiency on DBP mitigation during final chlorination of SRNOM: impact of $\mathrm{pH}$}

Experiments with $3 \mathrm{mgC} \mathrm{L}^{-1}$ of SRNOM were carried out at $\mathrm{pH}$ 6.5 (40 mM phosphate) without and with bromide (150 $\left.\mathrm{mg} \mathrm{L}^{-1}\right)$. The AOX, THM and HAN formations at $\mathrm{pH} 6.5$ are given in Fig. S9 (ESI) and were compared to the corresponding experiments at $\mathrm{pH} 8$ (40 mM borate, Fig. 1).

\subsubsection{Chlorination alone.}

Without pre-oxidation, during chlorination of SRNOM higher concentrations of AOX and HANs were produced at $\mathrm{pH} 6.5$ (17.6-18.2 $\mu \mathrm{M}$ of AOX, 74-87 nM of HANs) (Figs. S9a, b, e, f, ESI) compared to $\mathrm{pH} 8(15.7-16.6 \mu \mathrm{M}$ of $\mathrm{AOX}$ and $45-50 \mathrm{nM}$ of HANs) (Figs. 1a, b, g, h). However, THM formation was lower at pH 6.5 (1.9-2.1 $\mu \mathrm{M}$, Figs. S9c, d, ESI) compared to pH 8 (2.8$2.9 \mu \mathrm{M}$, Figs. $1 \mathrm{~d}, \mathrm{e})$. Therefore, at $\mathrm{pH} 6.5, \mathrm{THMs}$ accounted for a significantly lower relative contribution to AOX compared to pH 8 (32-35\% vs 49-54\%). The lower HAN and higher THM formations at higher $\mathrm{pH}$ are consistent with their base-catalyzed degradation and formation, respectively. ${ }^{30,}{ }^{31}$ However, the brominated HANs were not significantly affected by the $\mathrm{pH}$, in agreement with the lower impact of $\mathrm{pH}$ on their stability compared to the $\mathrm{Cl}-\mathrm{HANs}{ }^{30}$

\subsubsection{Pre-oxidation followed by chlorination.}

$3 \mathrm{mgC} \mathrm{L}^{-1}$ of SRNOM buffered at $\mathrm{pH} 6.5$ ( $40 \mathrm{mM}$ phosphate) was pre-treated with low and medium doses (medium and high for $\mathrm{Mn}(\mathrm{VII})$ ) of each oxidant, in absence or presence of bromide $\left(150 \mu \mathrm{g} \mathrm{L}^{-1}\right)$. To compare the impact of $\mathrm{pH}$ on the pre-oxidation efficiency, the DBP formation after post-chlorination was normalized based on the samples without pre-oxidation (Fig. 5, Figs. S10, S11, ESI).

For a medium oxidant dose, a larger fraction of the AOX was mitigated at $\mathrm{pH} 6.5$ for $\mathrm{Fe}(\mathrm{VI})$ and $\mathrm{O}_{3}-\mathrm{t}-\mathrm{BuOH}$ with about $15-$ $20 \%$ and $60 \%$ AOX mitigation, respectively, compared to only $<2 \%$ and $40 \%$ at pH 8 (Fig. 5). As shown in Fig. 5, to achieve a relative $\mathrm{AOX}$ mitigation of $15-20 \%, \mathrm{Fe}(\mathrm{VI})$ doses of about 15 or $50 \mu \mathrm{M}$ were needed at $\mathrm{pH} 6.5$ or 8 , respectively. Similarly, to achieve $60 \%$ of relative $\mathrm{AOX}$ mitigation a $\mathrm{O}_{3}-\mathrm{t}-\mathrm{BuOH}$ dose 3 times higher was needed at $\mathrm{pH} 8$ compared to $\mathrm{pH}$ 6.5. The relative mitigation of THMs also increased when decreasing the $\mathrm{pH}$ after $\mathrm{O}_{3}-\mathrm{t}$-BuOH pre-oxidation (Fig. S11, ESI). The improved mitigation of THMs but not HANs at lower $\mathrm{pH}$ by $\mathrm{O}_{3}-t-\mathrm{BuOH}$ is consistent with a previous study (conducted without hydroxyl radical scavenger and at a fixed chlorination $\mathrm{pH}$ ), where increasing the ozonation $\mathrm{pH}$ from 6 to 9 decreased THM abatement from $35 \%$ to $21 \%$ while the formation of HAN was abated by about $44 \%$ across the $\mathrm{pH}$ range. ${ }^{16}$ In contrast, lowering the $\mathrm{pH}$, decreased the relative reduction of AOX, THM and HAN formation by $\mathrm{Mn}(\mathrm{VII})$ (Figs. S10 to S12, ESI). No significant impact of the $\mathrm{pH}$ was observed on the $\mathrm{ClO}_{2}$ mitigation efficiency (Figs. S10 to S12, ESI).

\subsubsection{Discussion.}

Based on the relative mitigation of DBPs, the positive effect of a lower $\mathrm{pH}$ during pre-oxidation increased in the order $\mathrm{Mn}(\mathrm{VII})$ $<\mathrm{ClO}_{2}<\mathrm{Fe}(\mathrm{VI})<\mathrm{O}_{3}-t-\mathrm{BuOH}$. The better performance of $\mathrm{O}_{3}-t$ $\mathrm{BuOH}$ at lower $\mathrm{pH}$ can be attributed to a higher stability of $\mathrm{O}_{3}$ with a higher ozone exposure, leading to an enhanced cleavage of aromatic rings. ${ }^{32,46}$ In contrast to $\mathrm{O}_{3}$, the stability of $\mathrm{Fe}(\mathrm{VI})$ decreases with decreasing $\mathrm{pH} .{ }^{33}$ However, the $\mathrm{Fe}(\mathrm{VI})$ reactivity towards a large selection of organic NOM moieties also increases with decreasing $\mathrm{pH}$, while the $\mathrm{O}_{3}$ reactivity tends to decrease with decreasing $\mathrm{pH}^{36},{ }^{69-71}$ For example, when 
decreasing the $\mathrm{pH}$ from 8 to 6.5 , the apparent second order rate constants for the reactions of $\mathrm{Fe}(\mathrm{VI})$ with phenol or 4methylphenol increase by about 2-4 times, respectively, whereas they decrease about 30 times for the reactions with $\mathrm{O}_{3} .{ }^{36,69}$ The improved mitigation of $\mathrm{AOX}$ at lower $\mathrm{pH}$ for $\mathrm{Fe}(\mathrm{VI})$ and $\mathrm{O}_{3}-t-\mathrm{BuOH}$ suggests that the higher reactivity of $\mathrm{Fe}(\mathrm{VI})$, and/or of its degradation products, towards AOX precursors at lower $\mathrm{pH}$ counterbalanced its enhanced decomposition, while the higher stability of $\mathrm{O}_{3}$ at lower $\mathrm{pH}$ counterbalanced its lower reactivity towards AOX precursors.

It has to be noted that Fe(VI) self-decay is known to be affected by the type of buffer (by complexation of $\mathrm{Fe}(\mathrm{III})$ ). However, no significant differences were observed between phosphate and borate at the high buffer concentrations used in our experiments $(40 \mathrm{mM}) .^{72}, 73$ This was supported by the absence of precipitates at both $\mathrm{pHs}$.

The self-decays of $\mathrm{ClO}_{2}$ and $\mathrm{Mn}(\mathrm{VII})$ are slow and not affected by the $\mathrm{pH}$, hence, not affecting the oxidation efficiency. ${ }^{34}$ The lower efficiency of $\mathrm{Mn}(\mathrm{VII})$ pre-oxidation at lower $\mathrm{pH}$ could not be explained by its known chemistry (Figs. S10 to S12, ESI). It is important to state that the results are presented as relative abatement and that a higher formation of AOX and HANs was observed at $\mathrm{pH} 6.5$ compared to $\mathrm{pH} 8$ in samples without pre-oxidation.

Therefore, using a low $\mathrm{pH}$ during $\mathrm{Fe}(\mathrm{VI})$ or $\mathrm{O}_{3}$ pre-treatment to enhance the degradation of DBP precursors and a higher $\mathrm{pH}$ for disinfection might further reduce the overall DBP formation. This strategy has previously been tested for $\mathrm{O}_{3}$ pre-oxidation in a laboratory study and was shown to efficiently abate THMs while having no effect on HAN formation during postchlorination. ${ }^{16}$

\subsection{Pre-oxidation efficiency on DBP mitigation during final chlorination of SRNOM: calculated toxicity.}

\subsubsection{Chlorination alone.}

Chronic cytotoxicity (cell density reduction over $72 \mathrm{~h}$ exposure) and acute genotoxicity (DNA damage over $4 \mathrm{~h}$ exposure) are two toxicity indicators which have been assessed for a wide range of DBPs. ${ }^{25}$ The total relative cytotoxicity has previously been used to evaluate the impact of different treatment options on the DBP-induced toxicity potency, ${ }^{24,74,75}{ }^{76}$ The total relative cytotoxicity is estimated by dividing the concentration of each DBP (C) by its specific cytotoxicity concentration $\left(\mathrm{C}_{50}\right)$. $\mathrm{C}_{50}$ is the concentration of a specific DBP resulting in a $50 \%$ reduction of Chinese hamster ovary cell densities. ${ }^{25}$ The same approach can be applied for the specific genotoxicity of each DBP, represented by the migration of DNA from a Chinese hamster ovary nucleus, to calculate a total relative genotoxicity. ${ }^{25}$ The relative cytotoxicity results will be presented and compared to the relative genotoxicity. In absence of other important classes of DBPs such as haloacetic acids, haloacetaldehydes, halonitromethanes or haloacetamides, the obtained evolution presented below is not an exhaustive representation of the DBP-induced estimated toxicity, but provides a conceptual trend analysis.
Fig. 6 shows the relative cytotoxicity of THMs and HANs (bars) compared to the sum of THM and HAN concentrations (triangles), without and with bromide $\left(150 \mathrm{\mu g} \mathrm{L}^{-1}\right)$. The results for $500 \mu \mathrm{g} \mathrm{L}^{-1}$ bromide and for $\mathrm{pH} 6.5$ are presented in Fig. S14 and Fig. S15 (ESI), respectively. Although the HAN concentrations were very low compared to the THMs, they are more potent compounds $\left(\mathrm{C}_{50}=10^{-3}-10^{-2} \mathrm{M}\right.$ for THMs vs $10^{-6}-10^{-}$ ${ }^{4} \mathrm{M}$ for HANs). ${ }^{77}$ At $\mathrm{pH} 8$ and without bromide, THM concentrations represented $\geq 98 \%$ of the sum of the THMs and HANs concentrations, but accounted for $\leq 25 \%$ of the relative cytotoxicity (Fig. 6a). The contribution of THMs to the relative cytotoxicity was lower in presence of bromide ( $\leq 11 \%$ and $\leq 5 \%$ in presence of 150 and $500 \mathrm{\mu g} \mathrm{L}^{-1}$ bromide, respectively) (Fig. $6 \mathrm{~b}, \mathrm{Fig} . \mathrm{S} 14, \mathrm{ESI}$ ). If other potent DBPs were considered, THM contribution would be even lower. Since Br-DBPs are more potent toxicants than their chlorinated analogues, the total relative cytotoxicity increased with increasing bromide concentration. In presence of 150 and $500 \mu \mathrm{g} \mathrm{L}^{-1}$ bromide and at $\mathrm{pH} 8$, the relative cytotoxicity increased by a factor 2.4 or 8.8 , respectively, compared to samples without bromide, while the sum of the THM and HAN concentrations remained constant $(2.8 \pm 0.1 \mu \mathrm{M}$, Fig. 6 and Fig. S14, ESI).

In comparison to $\mathrm{pH} 8$, more HANs and less THMs were formed at pH 6.5 (Figs. 1d, e, g, h and Figs. S9c-f, ESI), hence increasing the total relative cytotoxicity by $50 \%$ in absence of bromide (compare data in Fig. 6a with Fig. S15a, ESI). It was previously shown that the brominated HANs were not increasing with decreasing $\mathrm{pH}$ (Fig. $1 \mathrm{~h}$ and Fig. S9f, ESI). Therefore, no significant difference in total relative cytotoxicity was observed between $\mathrm{pH} 6.5$ and 8 in presence of $150 \mu \mathrm{g} \mathrm{L}^{-1}$ bromide and without pre-oxidation (compare Fig. $6 \mathrm{~b}$ and Fig. $\mathrm{S} 15 \mathrm{~b}, \mathrm{ESI}$ ). Although THMs are cytotoxic, their genotoxicity is not quantifiable. ${ }^{77}$ Furthermore, the increase in genotoxicity when incorporating bromine in HANs is more pronounced compared to the cytotoxicity. DBAN cytotoxicity and genotoxicity are 20 and 58 times higher, respectively, compared to DCAN. ${ }^{25}$ Therefore, the increase in total relative genotoxicity was more pronounced when adding 150 and $500 \mathrm{\mu g} \mathrm{L}^{-1}$ bromide (4 and 25 times higher, respectively, compared to samples without bromide, Fig S16, ESI).

\subsubsection{Pre-oxidation followed by chlorination.}

In absence of bromide and at pH 6.5 and 8, both TCM and DCAN were mitigated by pre-oxidation (Figs. 1d, g and Figs. S9c, e, ESI). Therefore, the calculated total relative cytotoxicity decreased (Fig. 6a and Fig. S15a, ESI).

In presence of $150 \mu \mathrm{g} \mathrm{L}^{-1}$ bromide and at $\mathrm{pH} 8, \mathrm{DCAN}, \mathrm{BCAN}$ and TCM formations were mitigated while TBM, DBCM and DBAN concentrations were enhanced (Figs. 1e, h). Although DBAN levels were very low ( $<2 \mathrm{nM}$ without pre-oxidation), their increase can overcome, in some cases, the benefit of DCAN and BCAN mitigation in terms of total relative cytotoxicity (Fig. 6b, the impact of THMs was negligible). The detrimental effect of pre-oxidation treatment on the total relative cytotoxicity is emphasised for $\mathrm{O}_{3}-\mathrm{t}$-BuOH for solutions containing $150 \mu \mathrm{g} \mathrm{L}^{-1}$ bromide. The lowest total relative cytotoxicity was found for the lowest $\mathrm{O}_{3}$ dose (Fig. 6b). While higher doses further decreased 
DCAN, they also further enhanced DBAN formation. In addition, BCAN mitigation was less efficient at medium and high dose compared to low dose (Fig. 6b). Overall, the total relative cytotoxicity was reduced by $31 \%$ at the low $\mathrm{O}_{3}$ dose but only by $5 \%$ at the high $\mathrm{O}_{3}$ dose, whereas a continuous decrease of total DBP concentration was observed with increasing $\mathrm{O}_{3}$ dose (Fig. 6b). In presence of bromide, the cytotoxicity therefore contrasted with the continuous decrease of total DBP concentration. Similar effects were observed at pH 6.5 and 8 for all the oxidants (Fig. 6b, Fig. S15b, ESI).

The detrimental effect of pre-oxidation due to the enhanced formation of brominated HANs was more pronounced for total relative genotoxicity, especially in presence of $150 \mathrm{\mu g} \mathrm{L}^{-1}$ bromide for which $\mathrm{ClO}_{2}, \mathrm{Fe}(\mathrm{VI})$ and $\mathrm{O}_{3}-\mathrm{t}$ - $\mathrm{BuOH}$ pre-oxidation could enhance the total relative genotoxicity by up to 13,16 and $50 \%$, respectively (Fig. S16b, ESI). Nevertheless, a medium dose of $\mathrm{ClO}_{2}$ reduced DCAN and BCAN formation without enhancing DBAN formation at both $\mathrm{pH} 6.5$ and 8 , leading to an efficient reduction in both cytotoxicity and genotoxicity (5-47\%, Fig. 6b, Fig. S15b and Figs. S16b-c, ESI).

\subsubsection{Discussion.}

Other compounds, e.g., haloacetic acids, haloacetaldehydes, halonitromethanes or haloacetamides, were not monitored in this study and are likely to impact the cytotoxicity and genotoxicity. The formation of these compounds may be affected by pre-oxidation differently compared to HANs. In particular, DBPs such as halonitromethanes, ${ }^{13}, 16,40$ chloral hydrate or halopropanones can be enhanced by preoxidation. ${ }^{13,16,21,40}$

As brominated DBPs are generally more toxic than their chlorinated analogues, the increased relative cytotoxicity or genotoxicity with increasing bromide observed in Fig. 6 and Fig. S14-S16 (ESI) is likely to extend to other emerging DBPs. ${ }^{25,75}$

The impact of the $\mathrm{pH}$ on the formation of other DBPs may vary. For example, halopropanone and halonitromethane formation will decrease and increase, respectively, with increasing $\mathrm{pH} .{ }^{78,} 79$ Therefore, the overall impact of $\mathrm{pH}$ on cytotoxicity/genotoxicity would require a more extended DBP monitoring.

Although not exhaustive, the toxicity calculations presented here suggest that (i) THMs have a limited significance in terms of toxicity, and that they are not necessarily a good surrogate for the mitigation of other DBPs (here HANs) and (ii) in presence of bromide, the formation of brominated emerging DBPs needs to be considered, because they may heavily impact the overall toxicity.

\subsection{Pre-oxidation efficiency for DBP mitigation in a real groundwater.}

The different pre-oxidants were tested in a real groundwater, W20, (main characteristics are given in Table 2). $\mathrm{O}_{3}$ was also tested without $t-\mathrm{BuOH}$ to account for the impact of hydroxyl radical formation. The doses of pre-oxidants were chosen based on a 50\% reduction of the EDC for W20 and are shown in Table 1.
Without pre-oxidation, chlorination of W20 with a dose of $12.4 \mathrm{mg} \mathrm{L}^{-1}(72 \mathrm{~h})$ produced $23.8 \pm 0.9 \mu \mathrm{M} \mathrm{AOX}, 2.4 \pm 0.1 \mu \mathrm{M}$ THMs and $143 \pm 16 \mathrm{nM}$ HANs (Figs. 7a-c). Similarly to SRNOM at pH 6.5 (Figs. S9b, d, ESI), THMs and HANs represented $30 \%$ and $1.2 \%$ of the AOX, respectively (Figs. 7a-c). The presence of $144 \mu \mathrm{g} \mathrm{L}^{-1}$ bromide led to the formation of $\mathrm{Br}$-DBPs.

Under our experimental conditions, the AOX and HAN formation was reduced by pre-oxidation while THM formation was slightly enhanced by all pre-oxidants. AOX mitigation efficiency ranked in the order $\mathrm{O}_{3}-t-\mathrm{BuOH}(33 \%)>\mathrm{Fe}(\mathrm{VI})(25 \%)>$ $\mathrm{O}_{3}(14 \%)>\mathrm{Mn}(\mathrm{VII})(7 \%)>\mathrm{ClO}_{2}$ (5\%) (Fig. 7a). HAN mitigation efficiency ranked in the order $\mathrm{Fe}(\mathrm{VI})(72 \%)>\mathrm{O}_{3}-\mathrm{t}-\mathrm{BuOH}(60 \%)>$ $\mathrm{O}_{3}(56 \%)>\mathrm{Mn}(\mathrm{VII})(46 \%)>\mathrm{ClO}_{2}$ (41\%) (Fig. 7c). THM formation after pre-oxidation was found to increase after all pre-oxidation treatments, in the order $\mathrm{O}_{3}-\mathrm{t}-\mathrm{BuOH}(+7 \%)<\mathrm{ClO}_{2}(+13 \%)<\mathrm{Fe}(\mathrm{VI})$ $(+15 \%)<\mathrm{Mn}(\mathrm{VII})(+16 \%)<\mathrm{O}_{3}(+22 \%)$ (Fig. 7b). The increase in THM formation observed in the real water was a major difference with the results observed in the SRNOM extract (Figs. S9b, d, ESI) and contrasted with the decrease in AOX (Fig. 7a). This increase in THM formation may be explained by the difference in NOM characteristics possibly leading to a higher transformation of activated aromatic compounds to aliphatic $\beta$ keto-acid and $\beta$-diketone structures which lead to less halogenation (AOX decrease) but a higher yield of THMs. ${ }^{61}$ Higher pre-oxidant dosage may be necessary to efficiently oxidize THM precursors.

Similar to SRNOM, the $\mathrm{AOBr}$ formation was not significantly affected by pre-oxidation ( $\leq 10 \%$ reduction, Fig. $7 a$ ) due to the excess of chlorine, re-oxidising bromide until complete incorporation of bromine in NOM. The formation of brominated and chlorinated THMs was enhanced to a similar extent by $\mathrm{ClO}_{2}$, $\mathrm{Fe}(\mathrm{VI})$ and $\mathrm{Mn}(\mathrm{VII})$, while $\mathrm{O}_{3}$ (with and without $t$ - $\mathrm{BuOH}$ ) enhanced the brominated THMs to a slightly higher extent compared to the chlorinated THMs (Fig. 7b). This was illustrated by the increase of the BSF from $9 \%$ to $15 \%$ and $13 \%$ after pre-oxidation by $\mathrm{O}_{3}-\mathrm{t}-\mathrm{BuOH}$ and $\mathrm{O}_{3}$, respectively (Fig. $7 \mathrm{~b}$ ). The sum of brominated $\mathrm{HANs}$ was efficiently mitigated by $\mathrm{ClO}_{2}$ and $\mathrm{Fe}(\mathrm{VI})(38-43 \%)$ while $\mathrm{O}_{3}-\mathrm{t}-\mathrm{BuOH}, \mathrm{O}_{3}$ and $\mathrm{Mn}(\mathrm{VII})$ had little impact (7-12\%) (Fig. 7c). Furthermore, $\mathrm{O}_{3}-\mathrm{t}-\mathrm{BuOH}$ and $\mathrm{O}_{3}$ strongly enhanced the formation of DBAN (+333-362\%, Fig. 7c), for which the concentrations were still low (about $6 \mathrm{nM}$ ). Overall, $\mathrm{ClO}_{2}$ was the only oxidant that mitigated the formation of chlorinated and brominated HANs to a similar extent while $\mathrm{O}_{3}-\mathrm{t}-\mathrm{BuOH}, \mathrm{O}_{3}, \mathrm{Fe}(\mathrm{VI})$ and $\mathrm{Mn}(\mathrm{VII})$ increased the BSF from $7 \%$ to $21 \%, 19 \%, 16 \%$ and $12 \%$, respectively (Fig. $7 \mathrm{c}$ ). In comparison to $\mathrm{O}_{3}$ alone, the presence of $t-\mathrm{BuOH}$ increased the $\mathrm{O}_{3}$ exposure and thus improved the mitigation of $A O X$ and HANs while the increase of THMs was limited (Fig. 7).

Finally, for the real water, the efficiency of pre-oxidation on the calculated reduction of the relative cytotoxicity ranked in the order $\mathrm{Fe}(\mathrm{VI})(54 \%)>\mathrm{ClO}_{2}(39 \%)>\mathrm{Mn}(\mathrm{VII})(29 \%)>\mathrm{O}_{3}-\mathrm{t}-\mathrm{BuOH}$ $(11 \%)>\mathrm{O}_{3}$ (9\%) (Fig. S17a, ESI). The same ranking was observed for the total relative genotoxicity, although the enhancement of DBAN by $\mathrm{O}_{3}$ pre-oxidation (with and without $t-\mathrm{BuOH}$ ) led to an increase of the total relative genotoxicity (Fig S17b, ESI). The main difference compared to the DBP mitigation in SRNOM ( $\mathrm{pH}$ 6.5, $150 \mu \mathrm{g} \mathrm{L}^{-1}$ bromide, medium doses) was the higher 
efficiency of $\mathrm{Fe}(\mathrm{VI})$ and $\mathrm{Mn}(\mathrm{VII})$, relatively to the other oxidants, on HAN mitigation, and consequently on the cumulative estimated toxicity, in W20.

\section{Conclusions}

Pre-oxidation has been shown to be a viable option to reduce DBP formation during post-chlorination. Based on an equivalent $\mathrm{EDC}$ reduction, $\mathrm{O}_{3}-\mathrm{t}-\mathrm{BuOH}$ was generally the most efficient oxidant to mitigate total AOX, total THMs and total HANs while $\mathrm{Mn}$ (VII) was often the least efficient option, particularly for THMs.

The doses of $\mathrm{O}_{3}\left(2.0-94.3 \mu \mathrm{M}, 0.1-4.5 \mathrm{mg} \mathrm{L}^{-1}\right), \mathrm{Fe}(\mathrm{VI})(2.5-$ $\left.50 \mu \mathrm{M}, 0.1-2.8 \mathrm{mg} \mathrm{Fe}^{-1}\right)$ and $\mathrm{Mn}(\mathrm{VI})(1-8.6 \mu \mathrm{M}, 0.05-0.5 \mathrm{mg}$ $\left.\mathrm{Mn} \mathrm{L}^{-1}\right)$ were within the range of concentrations typically used in drinking water treatment, although $\mathrm{Fe}(\mathrm{VI})$ and $\mathrm{Mn}(\mathrm{VI})$ doses can be significantly higher. ${ }^{20,80,81}$ In practice, the $\mathrm{ClO}_{2}$ dose is limited to about $15 \mu \mathrm{M}\left(1 \mathrm{mg} \mathrm{L}^{-1}\right)$ due to the regulation of chlorite, ${ }^{82}$ which is lower than the highest dose used in this study ( $39 \mu \mathrm{M}, 2.8 \mathrm{mg} \mathrm{L}^{-1}$ ). However, chlorite can be removed in presence of $\mathrm{GAC}^{83}$ ferrous ions, ${ }^{84}$ or oxidized during postchlorination. During pre-oxidation, $\mathrm{O}_{3}$ decomposition leads to the formation of hydroxyl radicals which reduces its exposure, and decreases its efficiency, ${ }^{16}$ as confirmed by experiments (with and without $t-\mathrm{BuOH}$ ) in W20 (Figure 7).

Decreasing the $\mathrm{pH}$ increased the concentration of AOX and HANs while decreasing that of THMs after chlorination. Compared to samples without pre-oxidation, a lower $\mathrm{pH}$ improved the relative AOX mitigation by $\mathrm{O}_{3}-\mathrm{t}-\mathrm{BuOH}$ and $\mathrm{Fe}(\mathrm{VI})$ pre-oxidation and the relative THM mitigation by $\mathrm{O}_{3}$-t-BuOH pre-oxidation. However, a lower $\mathrm{pH}$ was decreasing the relative mitigation of all DBPs by $\mathrm{Mn}(\mathrm{VII})$. To minimize the concentration of the AOX and HANs after post-chlorination, pre-oxidation with $\mathrm{O}_{3}$ or $\mathrm{Fe}(\mathrm{VI})$ should be carried out at lower $\mathrm{pH}$, while raising the $\mathrm{pH}$ before postchlorination. Other DBP classes would need to be evaluated as $\mathrm{pH}$ can impact their formation differently. ${ }^{78,79}$

While $\mathrm{Cl}$-DBPs were efficiently mitigated, in presence of bromide the mitigation efficiency of Br-DBPs was much lower. The extent of specific DBP mitigation was anticorrelated to the number of bromine atoms in the compounds. In many cases, highly brominated DBPs were enhanced by increasing the preoxidant doses, with $\mathrm{O}_{3}-t-\mathrm{BuOH}$ generally having the highest detrimental effect.

The assessment of toxicity based on individual relative cytotoxicity of THMs and HANs suggests that regulated THMs are not significantly affecting the DBP-induced toxicity, especially in presence of bromide, and are not a good surrogate for the mitigation of more potent DBPs such as HANs. Conversely, the impact of pre-oxidation on HAN formation is likely to be an important factor for toxicity assessment, and the enhancement of DBAN was a major factor counteracting the efficiency of pre-oxidation in terms of relative toxicity for all oxidants, particularly $\mathrm{O}_{3}$. Rather than a decreasing relative toxicity with increasing doses of oxidants, optimal conditions were often observed at low or medium doses. Such conditions would also be desired to avoid excessive formation of bromate after $\mathrm{O}_{3}$ pre-oxidation of bromide-containing waters, ${ }^{85}$ or of chlorite after $\mathrm{ClO}_{2}$ pre-oxidation. The formation of other DBPs such as the widespread haloacetic acids or other very potent DBPs such as haloacetamide, haloketones, halonitromethanes and iodinated DBPs, should heavily influence the relative toxicity, ${ }^{77}$ and their formation may be impacted very differently upon pre-oxidation. ${ }^{14,86}$ Given the large pool of DBPs that may affect the toxicity, toxicity assays should be performed to fully evaluate the efficiency of the different pre-oxidation strategies.

The present study compares the effects of oxidative pretreatments on DBP precursors. The same chlorine dose was used with and without pre-oxidation, which led to chlorine residuals much higher than $1.5 \mathrm{mgCl}_{2} \mathrm{~L}^{-1}$ in pre-oxidized samples (Fig. S18, ESI). In practice, the chlorine dose could therefore be optimized, which will reduce the overall formation of DBPs. Furthermore, supplementary treatments are likely to be applied between pre-oxidation and disinfection such as coagulation-sedimentation-filtration or the use of biofiltration to remove the assimilable organic carbon and/or DBP precursors that may arise from pre-oxidation, notably from $\mathrm{O}_{3}$, $\mathrm{Fe}(\mathrm{VI})$ and $\mathrm{Mn}(\mathrm{VII})$ treatment. $^{51}$

\section{Conflicts of interest}

There are no conflicts to declare.

\section{Acknowledgements}

We acknowledge Peter Hopper for his assistance with GC-MS. Curtin University (Curtin International postgraduate Research Scholarship) and Curtin Water Quality Research Centre are also acknowledged for providing financial support for V.R.

\section{Notes and references}

1 U. von Gunten, Oxidation Processes in Water Treatment: Are We on Track?, Environ. Sci. Technol., 2018, 52, 5062-5075.

2 G. Hua and D. A. Reckhow, Effect of pre-ozonation on the formation and speciation of DBPs, Water Res., 2013, 47, 4322-4330.

3 Y. Jiang, J. E. Goodwill, J. E. Tobiason and D. A. Reckhow, in Ferrites and Ferrates: Chemistry and Applications in Sustainable Energy and Environmental Remediation, American Chemical Society, 2016, vol. 1238, ch. 16, pp. 421-437.

$4 \quad$ K. S. Werdehoff and P. C. Singer, Chlorine Dioxide Effects on THMFP, TOXFP, and the Formation of Inorganic Byproducts, J. Am. Water Works Ass., 1987, 79, 107-113.

5 V. Rougé, S. Allard, J.-P. Croué and U. von Gunten, In Situ Formation of Free Chlorine During $\mathrm{ClO} 2$ Treatment: Implications on the Formation of Disinfection Byproducts, Environ. Sci. Technol., 2018, 52, 13421-13429.

6 J. Terhalle, P. Kaiser, M. Jütte, J. Buss, S. Yasar, R. Marks, H. Uhlmann, T. C. Schmidt and H. V. Lutze, Chlorine dioxide Pollutant transformation and formation of hypochlorous acid as a secondary oxidant, Environ. Sci. Technol., 2018, 52, 9964-9971. 
Y. Lee and U. von Gunten, Oxidative transformation of micropollutants during municipal wastewater treatment: Comparison of kinetic aspects of selective (chlorine, chlorine dioxide, ferrateVI, and ozone) and non-selective oxidants (hydroxyl radical), Water Res., 2010, 44, 555-566.

R. H. Waldemer and P. G. Tratnyek, Kinetics of contaminant degradation by permanganate, Environ. Sci. Technol., 2006, 40, 1055-1061.

9 C. Singer Philip, Control of Disinfection By-Products in Drinking Water, J. Environ. Eng., 1994, 120, 727-744.

10 J.-Q. Jiang, S. Wang and A. Panagoulopoulos, The exploration of potassium ferrate(VI) as a disinfectant/coagulant in water and wastewater treatment, Chemosphere, 2006, 63, 212-219.

J.-J. Chen, H.-H. Yeh and I. C. Tseng, Effect of ozone and permanganate on algae coagulation removal - Pilot and bench scale tests, Chemosphere, 2009, 74, 840-846.

J. Ma and G. Li, Laboratory and Full-Scale Plant Studies of Permanganate Oxidation as an Aid in Coagulation, Water Sci. Technol., 1993, 27, 47-54.

X. Yang, W. Guo and W. Lee, Formation of disinfection byproducts upon chlorine dioxide preoxidation followed by chlorination or chloramination of natural organic matter, Chemosphere, 2013, 91, 1477-1485.

X. Yang, W. Guo, X. Zhang, F. Chen, T. Ye and W. Liu, Formation of disinfection by-products after pre-oxidation with chlorine dioxide or ferrate, Water Res., 2013, 47, 58565864.

E. C. Wert and F. L. Rosario-Ortiz, Effect of Ozonation on Trihalomethane and Haloacetic Acid Formation and Speciation in a Full-Scale Distribution System, Ozone-Sci. Eng., 2011, 33, 14-22.

16 G. A. de Vera, D. Stalter, W. Gernjak, H. S. Weinberg, J. Keller and M. J. Farré, Towards reducing DBP formation potential of drinking water by favouring direct ozone over hydroxyl radical reactions during ozonation, Water Res., 2015, 87, 49-58.

17 Y. Jiang, J. E. Goodwill, J. E. Tobiason and D. A. Reckhow, Impacts of ferrate oxidation on natural organic matter and disinfection byproduct precursors, Water Res., 2016, 96, 114-125.

18 Z. Liu, Y.-L. Lin, W.-H. Chu, B. Xu, T.-Y. Zhang, C.-Y. Hu, T.-C. Cao, N.-Y. Gao and C.-D. Dong, Comparison of different disinfection processes for controlling disinfection byproduct formation in rainwater, J. Hazard. Mater., 2020, 385, 121618

19 J. Liu, H. Lujan, B. Dhungana, W. C. Hockaday, C. M. Sayes, G. P. Cobb and V. K. Sharma, Ferrate(VI) pretreatment before disinfection: An effective approach to controlling unsaturated and aromatic halo-disinfection byproducts in chlorinated and chloraminated drinking waters, Environ. Int., 2020, 138, 105641.

20 P. C. Singer, J. H. Borchardt and J. M. Colthurst, The Effects of Permanganate Pretreatment on Trihalomethane Formation in Drinking Water, J. Am. Water Works Ass., 1980, 72, 573-578.

21 Y. Jiang, J. E. Goodwill, J. E. Tobiason and D. A. Reckhow, Comparison of ferrate and ozone pre-oxidation on disinfection byproduct formation from chlorination and chloramination, Water Res., 2019, 156, 110-124.
G. Hua and D. A. Reckhow, Evaluation of bromine substitution factors of DBPs during chlorination and chloramination, Water Res., 2012, 46, 4208-4216.

23 M. Langsa, A. Heitz, C. A. Joll, U. von Gunten and S. Allard, Mechanistic Aspects of the Formation of Adsorbable Organic Bromine during Chlorination of Bromidecontaining Synthetic Waters, Environ. Sci. Technol., 2017, 51, 5146-5155.

24 S. Allard, J. Tan, C. A. Joll and U. von Gunten, Mechanistic Study on the Formation of $\mathrm{Cl}-/ \mathrm{Br}$-/l-Trihalomethanes during Chlorination/Chloramination Combined with a Theoretical Cytotoxicity Evaluation, Environ. Sci. Technol., 2015, 49, 11105-11114.

E. D. Wagner and M. J. Plewa, CHO cell cytotoxicity and genotoxicity analyses of disinfection by-products: An updated review, J. Env. Sci., 2017, 58, 64-76.

26 S. Allard, C. E. Nottle, A. Chan, C. Joll and U. von Gunten, Ozonation of iodide-containing waters: Selective oxidation of iodide to iodate with simultaneous minimization of bromate and I-THMs, Water Res., 2013, 47, 1953-1960.

27 U. von Gunten and J. Hoigne, Bromate formation during ozonation of bromide-containing waters: Interaction of ozone and hydroxyl radical reactions, Environ. Sci. Technol., 1994, 28, 1234-1242.

$28 \mathrm{~J}$. Hoigné and $\mathrm{H}$. Bader, Kinetics of reactions of chlorine dioxide (OCIO) in water-I. Rate constants for inorganic and organic compounds, Water Res., 1994, 28, 45-55.

29 Y. Jiang, J. E. Goodwill, J. E. Tobiason and D. A. Reckhow, Bromide oxidation by ferrate(VI): The formation of active bromine and bromate, Water Res., 2016, 96, 188-197.

30 Y. Yu and D. A. Reckhow, Kinetic Analysis of Haloacetonitrile Stability in Drinking Waters, Environ. Sci. Technol., 2015, 49, 11028-11036.

31 C. J. Peters, R. J. Young and R. Perry, Factors influencing the formation of haloforms in the chlorination of humic materials, Environ. Sci. Technol., 1980, 14, 1391-1395.

32 C. von Sonntag and U. von Gunten, Chemistry of Ozone in Water and Wastewater Treatment: From Basic Principles to Applications, International Water Association, 2012.

33 Y. Lee, R. Kissner and U. von Gunten, Reaction of ferrate(VI) with $A B T S$ and self-decay of ferrate(VI): Kinetics and mechanisms, Environ. Sci. Technol., 2014, 48, 5154-5162.

34 I. N. Odeh, J. S. Francisco and D. W. Margerum, New Pathways for Chlorine Dioxide Decomposition in Basic Solution, Inorg. Chem., 2002, 41, 6500-6506.

35 B. Sun, J. Zhang, J. Du, J. Qiao and X. Guan, Reinvestigation of the Role of Humic Acid in the Oxidation of Phenols by Permanganate, Environ. Sci. Technol., 2013, 47, 1433214340.

36 J. Hoigné and $\mathrm{H}$. Bader, Rate constants of reactions of ozone with organic and inorganic compounds in water-II, Water Res., 1983, 17, 185-194.

37 J. D. Rush, J. E. Cyr, Z. Zhao and B. H. J. Bielski, The Oxidation of Phenol by Ferrate(VI) and Ferrate(V). A Pulse Radiolysis and Stopped-Flow Study, Free Radical Res., 1995, 22, 349360.

38 L. Simándi and É. Záhonyi-Budó, Relative reactivities of hydroxy compounds with short-lived manganese(V), Inorg. Chim. Acta, 1998, 281, 235-238.

39 W. K. Stuart, A. M. William, W. Paul and D. Aaron, Formation and control of emerging C- and N-DBPs in drinking water, J. Am. Water Works Ass., 2012, 104, E582-E595. 
40 J. Hu, W. Chu, M. Sui, B. Xu, N. Gao and S. Ding, Comparison of drinking water treatment processes combinations for the minimization of subsequent disinfection by-products formation during chlorination and chloramination, Chem. Eng. J., 2018, 335, 352-361.

41 G. A. de Vera, J. Keller, W. Gernjak, H. Weinberg and M. J. Farré, Biodegradability of DBP precursors after drinking water ozonation, Water Res., 2016, 106, 550-561.

42 V. Rougé, U. von Gunten and S. Allard, Pre-oxidation Treatment Efficiency of Natural Organic Matter: Electron Donating Capacity and UV Absorbance as Surrogate Parameters Water Res., Submitted.

43 M. Aeschbacher, C. Graf, R. P. Schwarzenbach and M. Sander, Antioxidant properties of humic substances, Environ. Sci. Technol., 2012, 46, 4916-4925.

N. Walpen, M. H. Schroth and M. Sander, Quantification of Phenolic Antioxidant Moieties in Dissolved Organic Matter by Flow-Injection Analysis with Electrochemical Detection, Environ. Sci. Technol., 2016, 50, 6423-6432.

45 J. Wenk, M. Aeschbacher, E. Salhi, S. Canonica, U. von Gunten and M. Sander, Chemical oxidation of dissolved organic matter by chlorine dioxide, chlorine, and ozone: Effects on its optical and antioxidant properties, Environ. Sci. Technol., 2013, 47, 11147-11156.

L. Önnby, E. Salhi, G. McKay, F. L. Rosario-Ortiz and U. von Gunten, Ozone and chlorine reactions with dissolved organic matter - Assessment of oxidant-reactive moieties by optical measurements and the electron donating capacities, Water Res., 2018, 144, 64-75.

47 C. S. Furman and D. W. Margerum, Mechanism of Chlorine Dioxide and Chlorate Ion Formation from the Reaction of Hypobromous Acid and Chlorite Ion, Inorg. Chem., 1998, 37, 4321-4327.

M. L. Granstrom and G. F. Lee, Generation and Use of Chlorine Dioxide in Water Treatment, J. Am. Water Works Ass., 1958, 50, 1453-1466.

D. J. Gates, The Chlorine Dioxide Handbook, American Water Works Association, 1998.

50 C. Li, X. Z. Li and N. Graham, A study of the preparation and reactivity of potassium ferrate, Chemosphere, 2005, 61, 537-543.

51 M. K. Ramseier, A. Peter, J. Traber and U. von Gunten, Formation of assimilable organic carbon during oxidation of natural waters with ozone, chlorine dioxide, chlorine, permanganate, and ferrate, Water Res., 2011, 45, 20022010.

52 Y. Lee, J. Yoon and U. von Gunten, Spectrophotometric determination of ferrate $(\mathrm{Fe}(\mathrm{VI}))$ in water by ABTS, Water Res., 2005, 39, 1946-1953.

53 S. Allard, J. W. A. Charrois, C. A. Joll and A. Heitz, Simultaneous analysis of 10 trihalomethanes at nanogram per liter levels in water using solid-phase microextraction and gas chromatography mass-spectrometry, J. Chromatogr. A, 2012, 1238, 15-21.

54 I. Kristiana, C. Joll and A. Heitz, Analysis of halonitriles in drinking water using solid-phase microextraction and gas chromatography-mass spectrometry, J. Chromatogr. A, 2012, 1225, 45-54.

55 M. Langsa, S. Allard, I. Kristiana, A. Heitz and C. A. Joll, Halogenspecific total organic halogen analysis: Assessment by recovery of total bromine, J. Env. Sci., 2017, 58, 340-348.
U. Pinkernell, B. Nowack, H. Gallard and U. von Gunten, Methods for the photometric determination of reactive bromine and chlorine species with ABTS, Water Res., 2000, 34, 4343-4350.

57 USEPA, Method 326.0: Determination of Inorganic Oxyhalide Disinfection By-Products in Drinking Water Using Ion Chromatography Incorporating the Addition of a Suppressor Acidified Postcolumn Reagent for Trace Bromate Analysis, 2002.

58 K. Chon, E. Salhi and U. von Gunten, Combination of UV absorbance and electron donating capacity to assess degradation of micropollutants and formation of bromate during ozonation of wastewater effluents, Water Res., 2015, 81, 388-397.

59 L. Önnby, N. Walpen, E. Salhi, M. Sander and U. Von Gunten, Two analytical approached to quantify the oxidation of dissolved organic matter by chlorine and ozone, Water Res., 2018.

X. Zhang, S. Echigo, R. A. Minear and M. J. Plewa, in Natural Organic Matter and Disinfection By-Products, American Chemical Society, 2000, vol. 761, ch. 19, pp. 299-314.

61 E. R. V. Dickenson, R. S. Summers, J.-P. Croué and H. Gallard Haloacetic acid and Trihalomethane Formation from the Chlorination and Bromination of Aliphatic $\beta$-Dicarbonyl Acid Model Compounds, Environ. Sci. Technol., 2008, 42, 3226-3233.

62 T. Bond, O. Henriet, E. H. Goslan, S. A. Parsons and B. Jefferson, Disinfection Byproduct Formation and Fractionation Behavior of Natural Organic Matter Surrogates, Environ. Sci. Technol., 2009, 43, 5982-5989.

63 E. N. Hidayah and H. H. Yeh, Effect of Permanganate Preoxidation to Natural Organic Matter and Disinfection by-Products Formation Potential Removal, J. Phys. Conf. Ser., 2018, 953, 012218.

64 G. Hua, D. A. Reckhow and J. Kim, Effect of Bromide and lodide Ions on the Formation and Speciation of Disinfection Byproducts during Chlorination, Environ. Sci. Technol., 2006, 40, 3050-3056.

65 K. Kumar and D. W. Margerum, Kinetics and mechanism of general-acid-assisted oxidation of bromide by hypochlorite and hypochlorous acid, Inorg. Chem., 1987, 26, 2706-2711.

P. Westerhoff, P. Chao and H. Mash, Reactivity of natural organic matter with aqueous chlorine and bromine, Water Res., 2004, 38, 1502-1513.

67 J. Criquet, E. M. Rodriguez, S. Allard, S. Wellauer, E. Salhi, C. A. Joll and $U$. von Gunten, Reaction of bromine and chlorine with phenolic compounds and natural organic matter extracts - Electrophilic aromatic substitution and oxidation, Water Res., 2015, 85, 476-486.

68 M. B. Heeb, J. Criquet, S. G. Zimmermann-Steffens and U. von Gunten, Oxidative treatment of bromide-containing waters: Formation of bromine and its reactions with inorganic and organic compounds - A critical review, Water Res., 2014, 48, 15-42.

69 Y. Lee, J. Yoon and U. von Gunten, Kinetics of the Oxidation of Phenols and Phenolic Endocrine Disruptors during Water Treatment with Ferrate (Fe(VI)), Environ. Sci. Technol., 2005, 39, 8978-8984.

70 Y. Lee, S. G. Zimmermann, A. T. Kieu and U. von Gunten, Ferrate (Fe(VI)) Application for Municipal Wastewater Treatment: A Novel Process for Simultaneous Micropollutant 
Oxidation and Phosphate Removal, Environ. Sci. Technol., 2009, 43, 3831-3838.

W. A. Pryor, D. H. Giamalva and D. F. Church, Kinetics of ozonation. 2. Amino acids and model compounds in water and comparisons to rates in nonpolar solvents, J. Am. Chem. Soc., 1984, 106, 7094-7100.

Y. Jiang, J. E. Goodwill, J. E. Tobiason and D. A. Reckhow, Effect of Different Solutes, Natural Organic Matter, and Particulate Fe(III) on Ferrate(VI) Decomposition in Aqueous Solutions, Environ. Sci. Technol., 2015, 49, 2841-2848.

M. Kolář, P. Novák, K. M. Šišková, L. Machala, O. Malina, J. Tuček, V. K. Sharma and R. Zbořil, Impact of inorganic buffering ions on the stability of $\mathrm{Fe}(\mathrm{vi})$ in aqueous solution: role of the carbonate ion, Phys. Chem. Chem. Phys., 2016, $18,4415-4422$.

E. M. Smith, M. J. Plewa, C. L. Lindell, S. D. Richardson and W. A. Mitch, Comparison of Byproduct Formation in Waters Treated with Chlorine and lodine: Relevance to Point-ofUse Treatment, Environ. Sci. Technol., 2010, 44, 84468452.

75 M. S. Ersan, C. Liu, G. Amy and T. Karanfil, The interplay between natural organic matter and bromide on bromine substitution, Sci. Total Environ., 2019, 646, 1172-1181.

S. S. Lau, X. Wei, K. Bokenkamp, E. D. Wagner, M. J. Plewa and W. A. Mitch, Assessing Additivity of Cytotoxicity Associated with Disinfection Byproducts in Potable Reuse and Conventional Drinking Waters, Environ. Sci. Technol., 2020, 54, 5729-5736.

M. J. Plewa, E. D. Wagner, M. G. Muellner, K.-M. Hsu and S. D. Richardson, in Disinfection By-Products in Drinking Water, American Chemical Society, 2008, vol. 995, ch. 3, pp. 3650.

H. Hong, Y. Xiong, M. Ruan, F. Liao, H. Lin and Y. Liang, Factors affecting THMs, HAAs and HNMs formation of Jin Lan Reservoir water exposed to chlorine and monochloramine, Sci. Total Environ., 2013, 444, 196-204.

G. Hua and D. A. Reckhow, DBP formation during chlorination and chloramination: Effect of reaction time. $\mathrm{pH}$, dosage, and temperature, J. Am. Water Works Ass., 2008, 100, 82$95+12$.

80

J. G. Jacangelo, N. L. Patania, K. M. Reagan, E. M. Aieta, S. W. Krasner and M. J. McGuire, Ozonation: Assessing Its Role in the Formation and Control of Disinfection By-products, J. Am. Water Works Ass., 1989, 81, 74-84.

81 J.-Q. Jiang and B. Lloyd, Progress in the development and use of ferrate(VI) salt as an oxidant and coagulant for water and wastewater treatment, Water Res., 2002, 36, 13971408.

USEPA, Disinfectants and Disinfection Byproducts final rule, 1998, 63, 69390-69476.

83

S. Sorlini and C. Collivignarelli, Chlorite removal with granular activated carbon, Desalination, 2005, 176, 255-265.

84

S. Sorlini and C. Collivignarelli, Chlorite removal with ferrous ions, Desalination, 2005, 176, 267-271.

85 F. Soltermann, C. Abegglen, C. Götz and U. von Gunten, Bromide Sources and Loads in Swiss Surface Waters and Their Relevance for Bromate Formation during Wastewater Ozonation, Environ. Sci. Technol., 2016, 50, 9825-9834.

86
W. Gan, V. K. Sharma, X. Zhang, L. Yang and X. Yang, Investigation of disinfection byproducts formation in ferrate(VI) pre-oxidation of NOM and its model compounds followed by chlorination, J. Hazard. Mater., 2015, 292, 197-204. 
Table 1 Doses of pre-oxidants applied, and corresponding EDC reduction at $\mathrm{pH}$ 8. The range of data represents triplicate experiments.

\begin{tabular}{|c|c|c|c|c|c|c|c|c|}
\hline \multirow[b]{2}{*}{ Oxidant } & \multicolumn{4}{|c|}{ Applied dose $(\mu \mathrm{M})$} & \multicolumn{4}{|c|}{ \% EDC reduction } \\
\hline & Low & $\begin{array}{l}\text { SRNOM } \\
\text { Medium }\end{array}$ & High & $\begin{array}{l}\text { W20 } \\
\text { Medium }\end{array}$ & Low & $\begin{array}{l}\text { SRNOM } \\
\text { Medium }\end{array}$ & High & $\begin{array}{l}\text { W20 } \\
\text { Medium }\end{array}$ \\
\hline $\mathrm{ClO}_{2}$ & 3.5 & 15.1 & 39.3 & 10 & $27 \pm 3$ & $56 \pm 2$ & $77 \pm 1$ & 50 \\
\hline $\mathrm{O}_{3}-t-\mathrm{BuOH}$ & 2.0 & 36.1 & 94.3 & 30 & $9 \pm 2$ & $61 \pm 2$ & $74 \pm 3$ & 59 \\
\hline $\mathrm{O}_{3}$ & & & & 30 & & & & 50 \\
\hline $\mathrm{Fe}(\mathrm{VI})$ & 2.5 & 14.7 & 50 & 24 & $20 \pm 2$ & $49 \pm 3$ & $68 \pm 2$ & 50 \\
\hline $\mathrm{Mn}(\mathrm{VII})$ & & 1 & 8.6 & 10 & & $36 \pm 2$ & $69 \pm 1$ & 42 \\
\hline
\end{tabular}

Table 2 Main characteristics of the real and synthetic waters. The EDC is presented relative to a $3 \mathrm{mgCL}^{-1}$ unbuffered SRNOM sample.

\begin{tabular}{|c|c|c|c|c|c|}
\hline NOM & pH & $\begin{array}{l}\text { DOC } \\
\left(\mathrm{mgC} \mathrm{L}^{-1}\right)\end{array}$ & $\begin{array}{l}\text { SUVA }_{254} \\
\left(\mathrm{~L} \mathrm{mgC}^{-1} \mathrm{~cm}^{-1}\right)\end{array}$ & $\begin{array}{l}\text { Bromide } \\
\left(\mu g \mathrm{~L}^{-1}\right)\end{array}$ & $\begin{array}{l}\text { Relative } \\
\text { EDC }\end{array}$ \\
\hline SRNOM & 6.5 or 8 ( $40 \mathrm{mM}$ phosphate or borate) & 3 & 4.0 & 0,150 or 500 & 1.04 \\
\hline W20 & 6.5 (natural water) & 4.5 & 3.4 & 144 & 2.04 \\
\hline
\end{tabular}




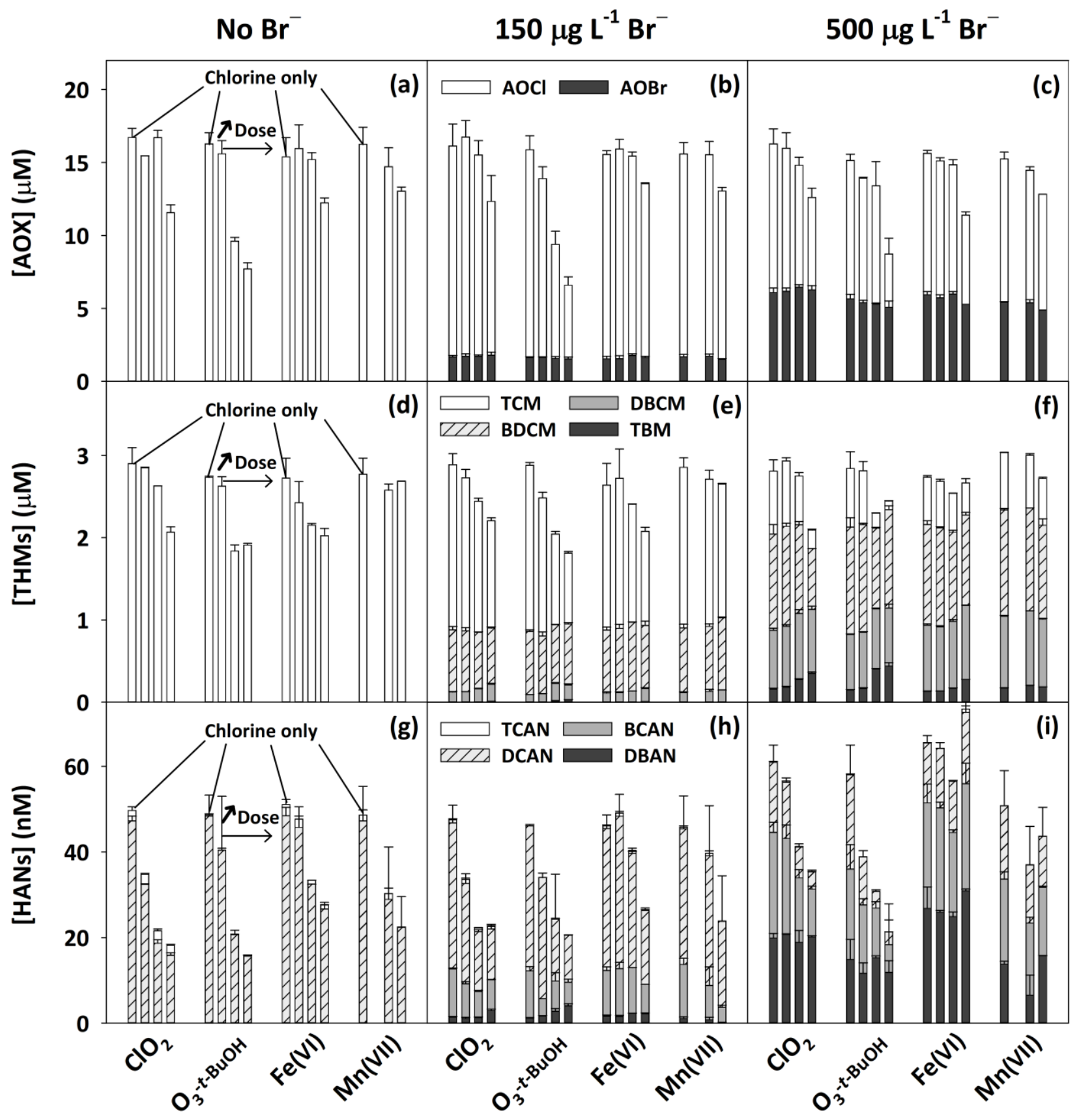

Figure 1 Formation of $(\mathrm{a}-\mathrm{c}) \mathrm{AOX}$, (d-f) THMs and(g-i) HANs after chlorination of SRNOM at pH 8, with and without (blank) pre-oxidation. For each pre-oxidant, the first bar represents

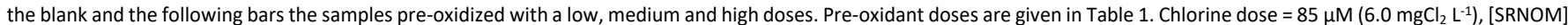
$=3 \mathrm{mgC} \mathrm{L}^{-1}, \mathrm{pH} 8\left(40 \mathrm{mM}\right.$ borate), [Br-] = 0-500 $\mathrm{g} \mathrm{L}^{-1}, 72 \mathrm{~h}$. Error bars represent the range of analytical results for duplicate experiments (except the high dose of Fe( $\left.\mathrm{VI}\right)$ and $\mathrm{Mn}(\mathrm{VII})$ for which error bars represent duplicate analysis). 


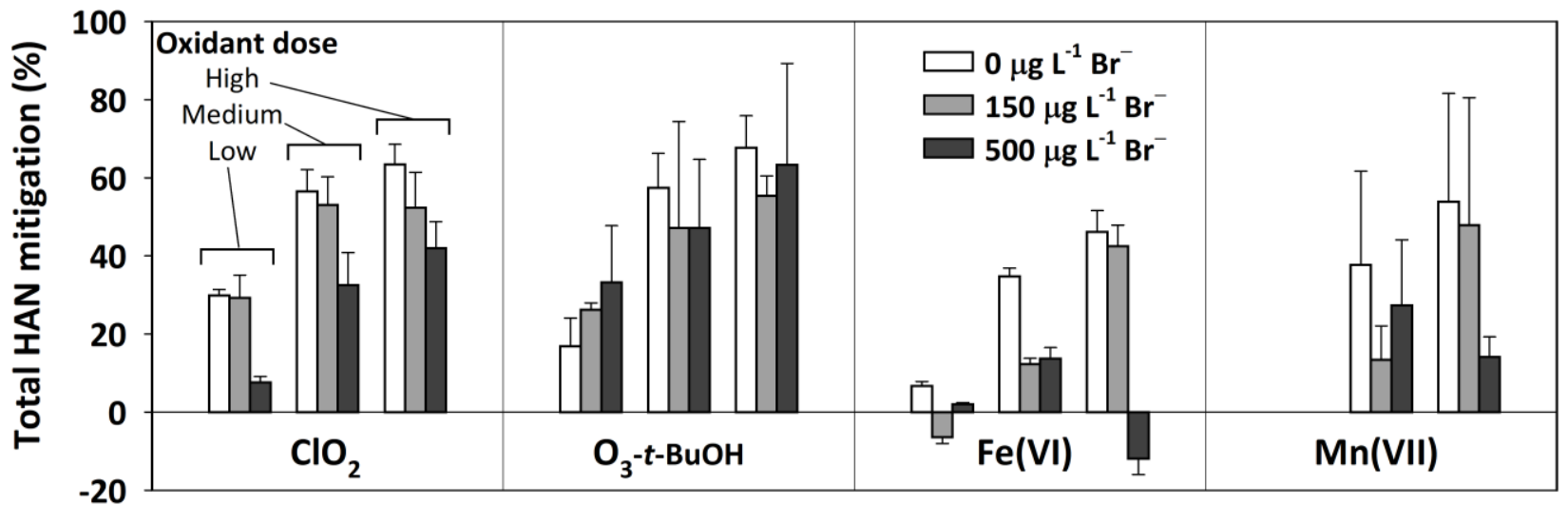

Figure 2 Impact of bromide on the total HAN mitigation by pre-oxidation of SRNOM with $\mathrm{ClO}_{2}, \mathrm{O}_{3}-t-\mathrm{BuOH}, \mathrm{Fe}(\mathrm{VI})$ and $\mathrm{Mn}(\mathrm{VII})$. The \% mitigation is presentend relatively to the $\mathrm{HAN}$ formation without pre-oxidation. A negative mitigation represents an increase in $\mathrm{HAN}$ formation. Pre-oxidant doses are given in Table $1 . \mathrm{Chlorine}$ dose $=85 \mu \mathrm{M}\left(6.0 \mathrm{mgCl} \mathrm{L}^{-1}\right)$, [SRNOM] $=3 \mathrm{mgC} \mathrm{L}^{-1}, \mathrm{pH} 8,72 \mathrm{~h}$. Error bars represent the range of analytical results for duplicate experiments (except the high dose of Fe(VI) and $\mathrm{Mn}(\mathrm{VII})$ for which error bars represent duplicate analysis).

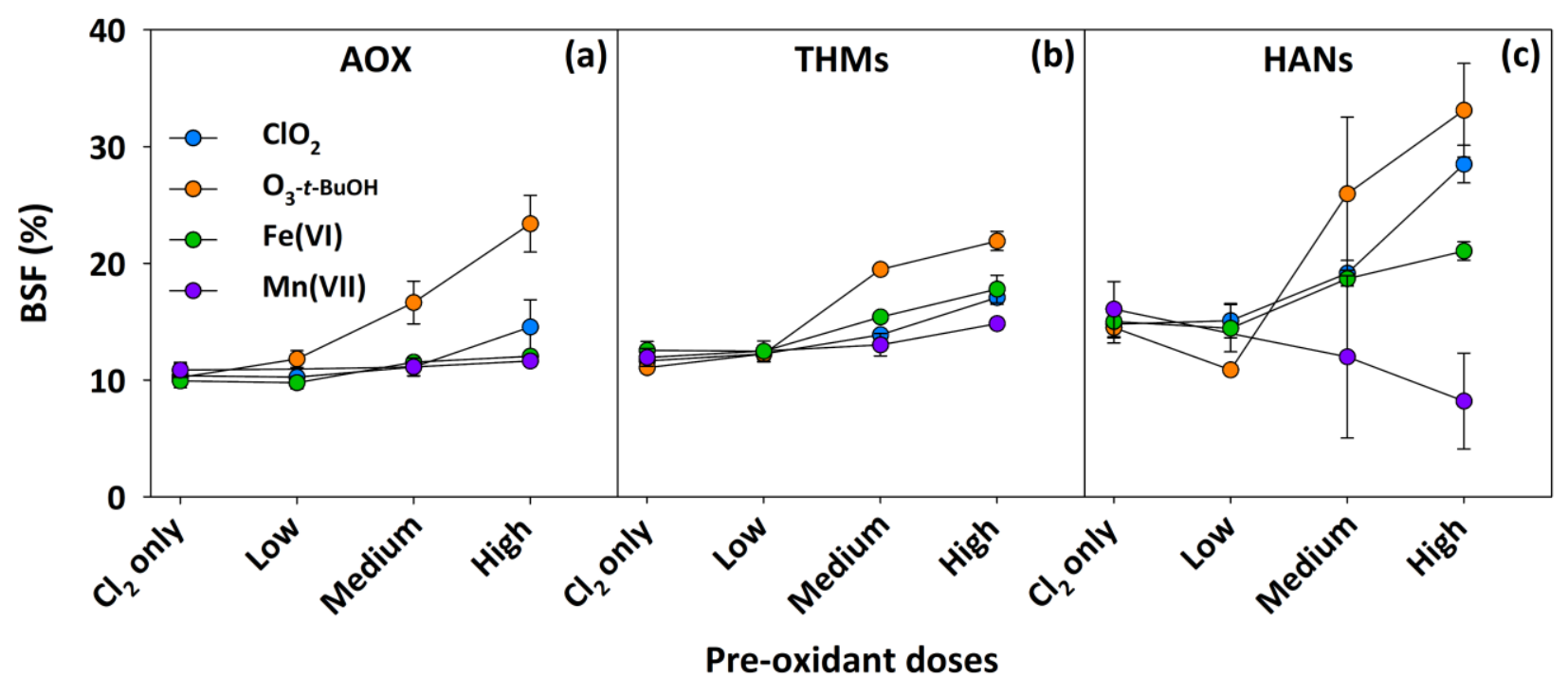

Figure 3 Bromine Substitution Factor (BSF) in (a) AOX, (b) THMs and (c) HANs after chlorination of SRNOM in presence of $150 \mu \mathrm{g} \mathrm{L}^{-1}$ bromide, with and without pre-oxidation. Pre-oxidant doses are given in Table 1. Chlorine dose $=85 \mu \mathrm{M}\left(6.0 \mathrm{mgCl}_{2} \mathrm{~L}^{-1}\right)$, [SRNOM] $=3 \mathrm{mgC} \mathrm{L}^{-1}, \mathrm{pH} 8,72 \mathrm{~h}$. Error bars represent the range of analytical results for duplicate experiments (except the high dose of $\mathrm{Fe}(\mathrm{VI})$ and $\mathrm{Mn}(\mathrm{VII})$ for which error bars represent duplicate analysis). 


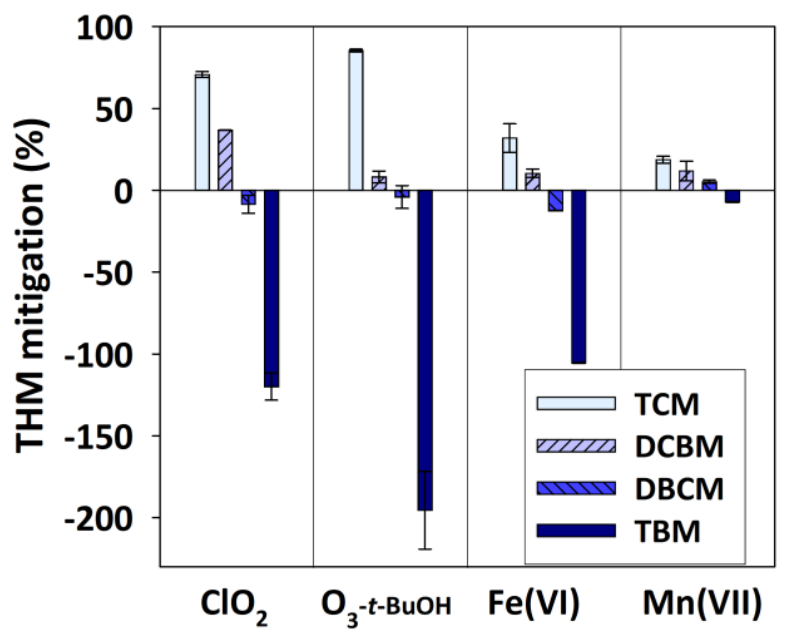

Figure 4 Chlorination of SRNOM: Mitigation of individual THMs by a high dose of pre-oxidants in presence of $500 \mu \mathrm{g} \mathrm{L}^{-1}$ bromide. The $\%$ mitigation is presentend relatively to the THM formation without pre-oxidation. A negative mitigation represents an increase in THM formation. Pre-oxidant doses: $\left[\mathrm{ClO}_{2}\right]=39.3 \mu \mathrm{M},\left[\mathrm{O}_{3}-t\right.$ $\mathrm{BuOH}]=94.3 \mu \mathrm{M},[\mathrm{Fe}(\mathrm{VI})]=50 \mu \mathrm{M},[\mathrm{Mn}(\mathrm{VII})]=8.6 \mu \mathrm{M}$. Chlorine dose $=85 \mu \mathrm{M}$ ( $\left.6.0 \mathrm{mgCl}_{2} \mathrm{~L}^{-1}\right)$, [SRNOM] $=3 \mathrm{mgC} \mathrm{L}^{-1}, \mathrm{pH} 8(40 \mathrm{mM}$ borate), $72 \mathrm{~h}$. Error bars represent the range of duplicate analysis for one experiment.

\section{$[\mathrm{Fe}(\mathrm{VI})](\mu \mathrm{M})$}

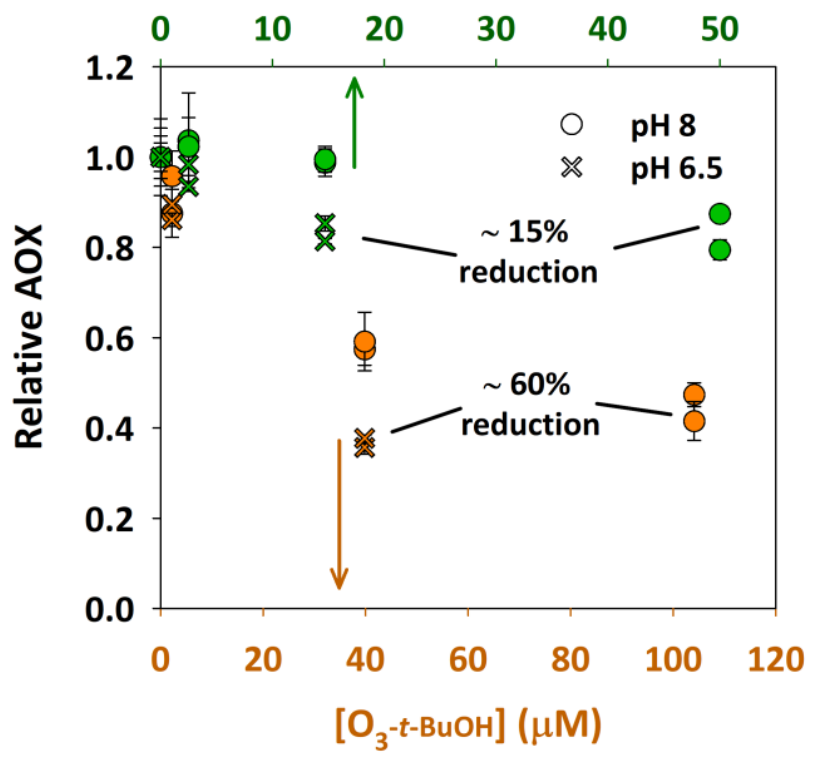

Figure 5 Chlorination of SRNOM: Relative AOX formation after $\mathrm{O}_{3}-\mathrm{t}-\mathrm{BuOH}$ (orange symbols) and $\mathrm{Fe}(\mathrm{VI})$ (green symbols) pre-oxidation at $\mathrm{pH} 6.5$ (crosses) and 8 (circles). Chlorine dose $=85 \mu \mathrm{M}\left(6.0 \mathrm{mgCl}_{2} \mathrm{~L}^{-1}\right)$, [SRNOM] $=3 \mathrm{mgC} \mathrm{L}^{-1},[\mathrm{Br}-]=0-150 \mu \mathrm{g} \mathrm{L}{ }^{-1}, 40$ $\mathrm{mM}$ phosphate $(\mathrm{pH} 6.5)$ or borate $(\mathrm{pH} 8), 72 \mathrm{~h}$. Error bars represent the range of duplicate analysis for one experiment. 


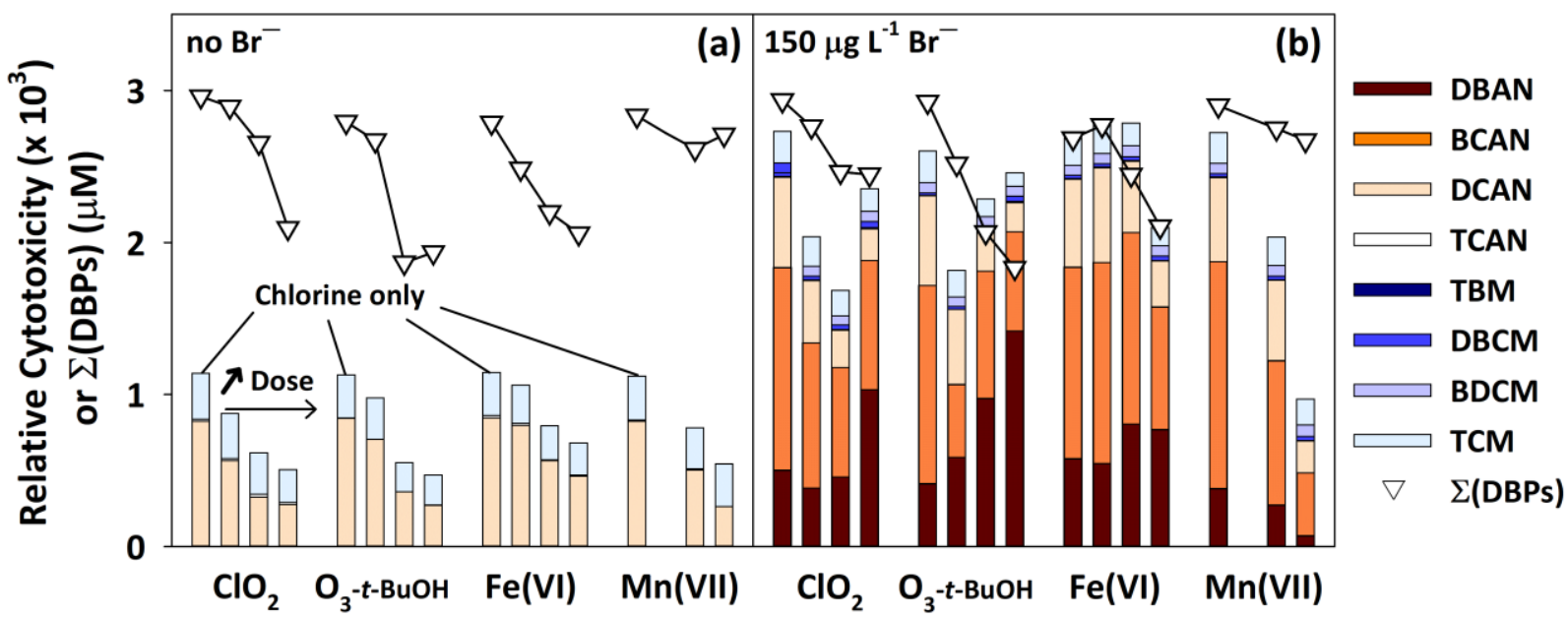

Figure 6 Calculated relative cytotoxicity (bars) compared to DBP formation (triangles) after chlorination of SRNOM and without/with pre-oxidation (a) without bromide and (b) with $150 \mu \mathrm{g} \mathrm{L}^{-1}$ bromide. Pre-oxidant doses are given in Table 1. Chlorine dose $=85 \mu \mathrm{M}\left(6.0 \mathrm{mgCl}_{2} \mathrm{~L}^{-1}\right)$, [SRNOM] $=3 \mathrm{mgC} \mathrm{L}^{-1}, \mathrm{pH} 8(40 \mathrm{mM}$ borate), $72 \mathrm{~h}$. For more clarity, error bars are not shown. 


\section{ARTICLE}

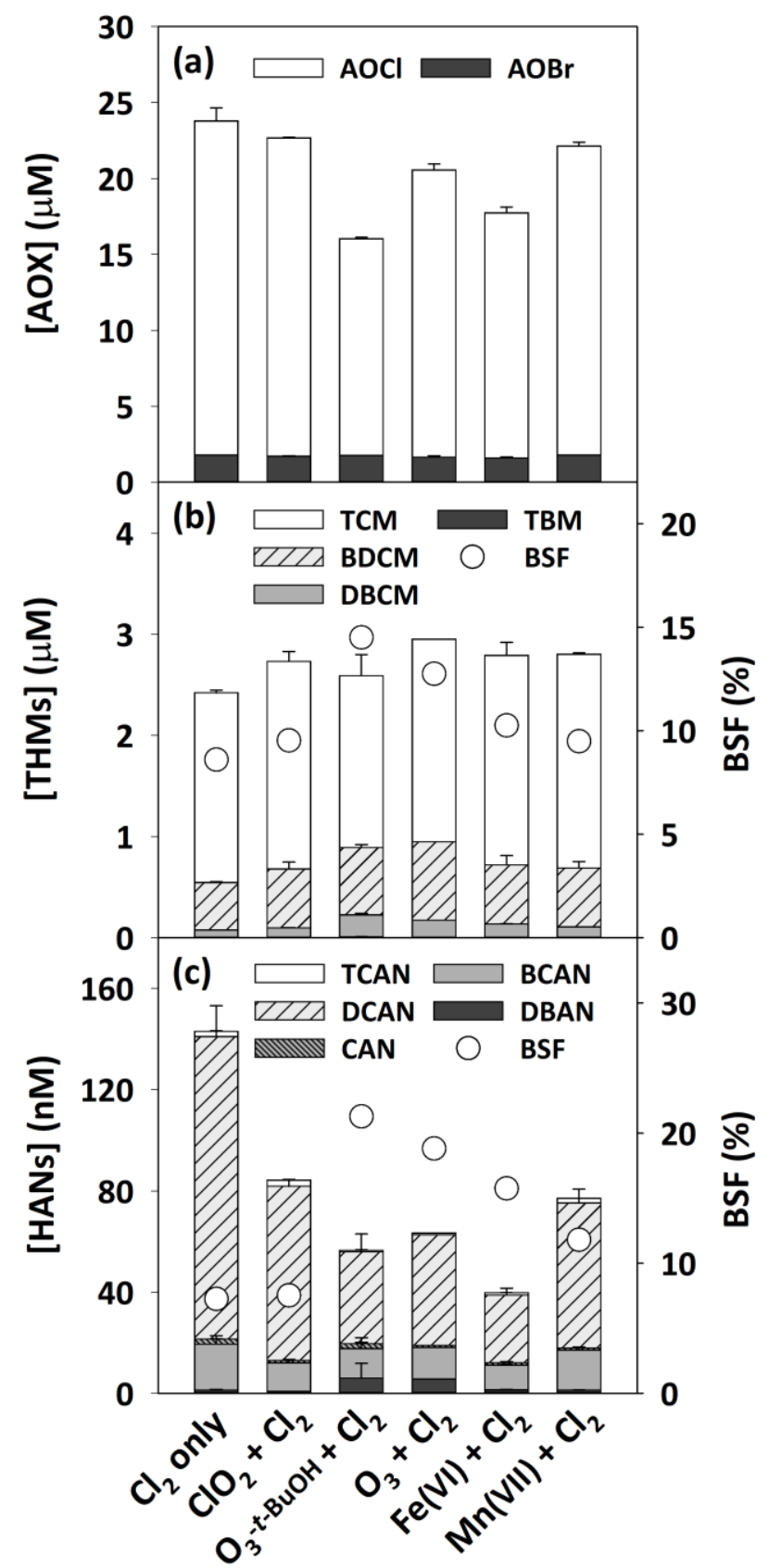

Figure 7 Chlorination of a real water (W20): Formation of (a) AOX, (b) THMs and (c) HANs without and with pre-oxidation. The bromine substitution factors (BSF) are also shown for THMs and HANs. Chlorine dose $=155 \mu \mathrm{M}\left(12.4 \mathrm{mgCl}_{2} \mathrm{~L}^{-1}\right), 72 \mathrm{~h}$. The pre-oxidant doses and the water characteristics are given in Table 1 and Table 2, respectively. Error bars represent the range of duplicate analysis for one experiment. 